\title{
Transcriptomic profiling of tissue environments critical for post- embryonic patterning and morphogenesis of zebrafish skin
}

\author{
Andrew J. Aman¹, Lauren M. Saunders*2, Sanjay R. Srivatsan², Cole Trapnell², David M. \\ Parichy ${ }^{1,3}$ \\ ${ }^{1}$ Department of Biology, University of Virginia, Charlottesville, VA \\ 2 Department of Genome Sciences, University of Washington, Seattle, WA \\ 3 Department of Cell Biology, University of Virginia, Charlottesville, VA \\ *these authors contributed equally
}

\begin{abstract}
Regulation of neural crest derived pigment cells and dermal cells that form skin appendages is broadly similar across vertebrate taxa. In zebrafish, organized pigment stripes and an array of calcified scales form simultaneously in the skin during post-embryonic development. Understanding mechanisms that regulate stripe patterning and dermal morphogenesis may lead to discovery of fundamental mechanisms that govern development of animal form. To learn about cell types and potential signaling interactions that govern skin patterning and morphogenesis we generated and analyzed single cell transcriptomes of skin with genetic or induced defects in pigmentation and squamation. These data reveal a previously undescribed population of ameloblast-like epidermal cells, suggest hormonal control of epithelialmesenchymal signaling, clarify the signaling network that governs scale papillae development, and identify the hypodermis as a crucial pigment cell support environment. These analyses provide new insights into the development of skin and pigmentation and highlight the utility of zebrafish for uncovering essential features of post-embryonic development in vertebrates.
\end{abstract}

\section{Keywords}

zebrafish, post-embryonic development, single-cell RNA-seq, dermis, epidermis, scales, elasmoid, melanophore, xanthophore, iridophore, pattern formation, thyroid hormone, Basonuclin-2, Ectodysplasin signaling 


\section{Introduction}

The steady-state chemistry of biological life on earth occurs within compartments bounded from the rest of the cosmos. Sophisticated integuments serve as the ultimate boundary and primary interface between biological organisms and their environments. Vertebrates have marvelous and varied skins, decorated with pigment patterns and arrayed with appendages such as feathers, fur or scales. Understanding the mechanistic underpinnings of animal form and phenotypic diversity is an enduring goal of basic biology and studying skin patterning and morphogenesis can advance that goal. Additionally, while human skin is a major factor in our outward appearance, bears all our physical interactions, and detects all our tactile sensations, it remains an incompletely understood and failure prone organ system.

Studying the skin of research organisms chosen based on phylogeny or experimental exigency can improve our understanding of regulatory mechanisms underlying its patterning and morphogenesis. Comparing developmental mechanisms across species can give insights into the origin and evolution of this important organ system and elucidate fundamental mechanisms of potential relevance to human dermatology. To this end, skin morphogenesis and patterning has been studied across a variety of organisms, yielding insights into both general and species-specific mechanisms (Duverger and Morasso, 2009; Chen et al., 2015; Patterson and Parichy, 2019; Aman and Parichy, 2020).

Zebrafish (Danio rerio) is an outstanding organism for studying vertebrate skin patterning and morphogenesis. Zebrafish skin, like all vertebrate skin, has a superficial epidermis composed of ectoderm-derived epithelial cells and an underlying dermis composed of mesoderm-derived mesenchymal cells and a collagenous stromal matrix (Le Guellec et al., 2004; Aman and Parichy, 2020). During post-embryonic development, zebrafish skin simultaneously develops an array of calcified scales and pigmented stripes. Both form superficially on the surface of the animal and are dispensable for survival, making them readily amenable to imaging and experimental perturbation, enabling analyses of underlying cellular dynamics and molecular mechanisms (Aman et al., 2018; Cox et al., 2018; Iwasaki et al., 2018; Rasmussen et al., 2018; Patterson and Parichy, 2019; De Simone et al., 2021).

To attain integrative insights into zebrafish skin patterning and morphogenesis we used single-cell transcriptional profiling and live imaging of skins from ectodysplasin a (eda) mutants, basonuclin 2 (bnc2) mutants, and hypothyroid fish (hypoTH) (Fig 1A). Eda-Edar-NF-kB signaling is a conserved pathway that is necessary for normal development of all tested vertebrate skin appendages (Kere et al., 1996; Srivastava et al., 1997; Kondo et al., 2001; Houghton et al., 2005; Harris et al., 2008; Di-Poï and Milinkovitch, 2016). Mutations in the signaling ligand Eda-A (Ectodysplasin-A), its receptor Edar, or downstream signal transduction molecules underlie the majority of human ectodermal dysplasias, hereditary disorders defined by loss of skin appendages and teeth (Cluzeau et al., 2011). Similarly, eda mutant zebrafish completely lack scales, though specific mechanisms linking Eda signaling to scale formation remain unclear (Harris et al., 2008). To learn more about potential interactions between pigment cells and their skin microenvironment, we profiled a mutant for bnc2, a conserved zinc finger containing protein implicated in human pigment variation and that acts through the tissue environment to promote pigment celll development in zebrafish (Lang et al., 2009; Patterson and Parichy, 2013; Visser et al., 2014; Endo et al., 2018; Ayoola et al., 2021). Finally, we profiled skins from hypothyroid fish (hypoTH), unable to synthesize thyroid hormone owing to transgene-mediated ablation of the thyroid gland (McMenamin et al., 2014). Thyroid hormone is a potent regulator of vertebrate skin development and thyroid dysfunction underlies debilitating skin pathologies (Mancino et al., 2021). TH is necessary for dermal morphogenesis and pigment 
cell maturation and pattern formation (McMenamin et al., 2014; Saunders et al., 2019; Aman et al., 2021).

Our analyses of transcriptomic states across wild-type and other backgrounds of zebrafish provide new evidence supporting homology of tissues forming scales in zebrafish with tissues forming teeth and scales of other vertebrates. They further point to a previously undescribed epidermal cell type that expresses transcripts encoding enamel matrix proteins, relevant to understanding the ancient origins of calcified tissues, and clarify the position of Eda within the signaling network that governs scale papilla induction. Finally, they identify a specialized population of dermal cell that supports pigment cells, thereby providing a permissive tissue environment for the self-organizing interactions of adult stripe formation.

\section{Results}

\section{sci-RNA-seq of whole skin reveals cell type diversity during post-embryonic development}

Skin is a large and complex organ system, with contributions from multiple embryonic germ layers and a variety of distinct cell types. Conveniently, pigment pattern formation and squamation occur simultaneously during post-embryonic development, in different layers of the skin (Fig 1B) (Aman et al., 2021). To capture individual transcriptomes from a minimally biased sampling of skin cells, we performed single nucleus combinatorial indexing (sci)-RNA-seq (Cao et al., 2017; Cao et al., 2019) on nuclei from pooled, fresh-frozen whole skins at 9.6 SSL, a key developmental stage during skin patterning and morphogenesis. At this stage of wild-type fish, all stages of scale morphogenesis are represented and a "primary" pigment pattern is apparent with secondary pattern elements just beginning to form (Fig 1A,B; Fig 1-S1) (Aman et al, 2019; Parichy et al, 2009).

To better understand the contributions of individual cell types and key factors involved in the major skin patterning events at this stage, we included 3 additional backgrounds representing distinct developmental perturbations: eda mutants, bnc2 mutants, and hypoTH fish. We processed all tissue in a single sci-RNA-seq experiment, barcoding each genotype by reverse transcription index during library preparation. In total, we recovered high quality transcriptomes from 144,466 individual nuclei with an average of 1,300 unique molecular identifiers (UMIs) and 720 genes detected per cell ( 60\% duplication rate). Cell recovery, UMls per cell, and numbers of genes detected were consistent across all sample groups (Fig 1-S2). We removed likely multiplets using Scrublet (11\%) (Wolock et al., 2019) and further processed the data and performed dimensionality reduction and clustering with Monocle3 (Cao et al., 2019). To characterize the cell types and developmental trajectories, we focused on the wild-type data alone (35,114 cells). Unsupervised clustering identified 43 distinct clusters that we classified into 22 major cell types by assessing expression of published markers for different skin and skinassociated cell types. The majority of cells were from epidermal and dermal populations. We also recovered less abundant cell types including pigment cells, lateral line cells, ionocytes and resident immune cells (Fig 1C, Fig 1-S3). As expected based on our stage selection, we recovered a large number of dermal scale forming cells (SFCs) and their progenitors (preSFCs). To assign cell types to all cells in the non-wild-type data, we used the Garnett software package (Pliner et al., 2019) to train a classifier using the wild-type cell type assignments and then apply that classifier to rapidly annotate cells from other backgrounds. We manually checked and corrected annotations where needed to fully resolve cell type assignments for all cells in the co-embedded space. 


\section{A heterogenous population of epidermal and dermal cells contributes to scale plate formation}

Like most extant fish species, zebrafish are adorned with a full coat of scales by juvenile stages. These scales represent one form of calcified, dermally derived skin appendages that cover the bodies of most fish species. Due to the preservation of these bony tissues in the fossil record, much is known about the evolutionary history of scale morphology and mineral content, yet the shared and divergent molecular mechanisms underlying the development of these appendages is just starting to be elucidated. Calcified dermal armor is an ancient vertebrate innovation, first appearing in the Ordovician 450 million years ago prior to the appearance of paired fins, jaws and teeth in the fossil record. Early calcified skin appendages were composed of unambiguous enamel, dentin and bone analogues, arranged in an overtly tooth-like histology (Smith et al., 2002; Märss, 2006; Sire et al., 2009). These traits have been retained in the skin appendages and teeth of phylogenetically far-flung vertebrates. While certain fishes, like sharks and gar, have overtly tooth-like scales, zebrafish scales are highly derived relative to this ancestral state. Histological and ultrastructural studies have shown that the zebrafish elasmoid scale is composed of weakly calcified collagenous matrix capped by hypermineralized outer and limiting layers (Quan et al., 2020). This morphology is common among bony fish. Based on fate mapping experiments, histology and analysis of osteoblast reporter transgenics, dermal cells with osteoblast-like properties are thought to deposit the bony matrices of the scale (Sire et al., 1997; Mongera and Nüsslein-Volhard, 2013; Shimada et al., 2013; Aman et al., 2018; Cox et al., 2018; Iwasaki et al., 2018; Rasmussen et al., 2018).

The evolutionary history of scales and teeth suggests that zebrafish scales-despite their highly derived morphology - might share features of their developmental anatomy with teeth and tooth-like skin appendages. In all overtly tooth-like protuberances of vertebrates, calcified matrices are deposited by two cooperating cell types, mesenchymal cells of dermal or neural crest origin that form dentin, bone or both, and overlying epithelial cells of epidermal origin that produce hypermineralized matrices like enamel (Sire, 1990; Sire and Huysseune, 2003). Hypothesizing that epidermis of zebrafish retains vestiges of this ancient function, we predicted that a subset of epidermal cells should express transcripts encoding enamel matrix proteins (EMPs) a conserved family of non-collagen matrix proteins that underly hypermineralization (Kawasaki, 2011; Kawasaki et al., 2021).

Actinopterygian fish, including zebrafish, are known already to synthesize a hypermineralized enameloid that is similar in hardness and matrix composition to the true enamel of tetrapod teeth. This material is associated with expression of conserved EMP genes, ambn (encoding Ameloblastin), enam (Enamelin) and scpp5 (Secretory calcium-binding phosphoprotein 5), which facilitate the ordered formation of calcium hydroxyapatite crystals (Kawasaki, 2011; Braasch et al., 2016; Kawasaki et al., 2021). We therefore analyzed the distribution of these transcripts across the whole skin, predicting such cells might be found among basal epidermal cells, as the zebrafish scale plate forms at the interface between these cells and underlying dermal cells (Fig 2A,B; Fig 2-S1) (Sire and Akimenko, 2004). Consistent with our prediction, we identified a small, but transcriptionally distinct population of basal epidermal cells that expressed all three EMP genes, suggesting that the hypermineralized outer layers of the scale are indeed enamel-like and identifying EMP expressing epidermal cells as a novel skin cell type (Fig 2C,D).

We next turned our attention to the dermal SFCs. These cells, frequently referred to as "scale osteoblasts," are thought to resemble mammalian osteoblasts (Metz et al., 2012; Aman et al., 2018; Cox et al., 2018; Iwasaki et al., 2018; De Simone et al., 2021). To compare SFCs with cell types like osteoblasts and odontoblasts, we additionally assessed the expression of well- 
characterized non-collagen matrix protein genes associated with various vertebrate calcified matrix types. Consistent with overall similarity among osteoblasts, odontoblasts and SFCs, we found expression of genes encoding bone specific matrix proteins including spp1 (Osteopontin), lum (Lumican), and chad (Chondroadherin) (Fig 2C,E) (Larsson et al., 1991; Raouf et al., 2002; Hessle et al., 2013; Venkatesh et al., 2014). Nevertheless, we failed to detect bone specific transcripts for ostn (Osteocrin) or bglap (Osteocalcin) (Fig 2C) (Thomas et al., 2003). In addition to bone specific transcripts, SFCs also expressed EMPs. We detected robust enam and weak scpp5 expression, but not ambn in SFCs (Fig 2C). These transcripts are not typically found in osteoblasts, including the cells that generate attachment bone underlying the tooth-like scales of the gar (Kawasaki et al., 2021).

Transcripts of sparc (Osteonectin), most often associated with mineralized matrix formation, were expressed broadly in skin (Fig 2C), raising the possibility of additional roles beyond assembly of calcified matrix (Rosset and Bradshaw, 2016). Transcripts considered diagnostic for mammalian odontoblasts, Dmp1 (Dentin Matrix Protein 1) and Dspp (Dentinogenesis and Dentin Sialophosphoprotein), are not present in Actinopterygian genomes (MacDougall et al., 1996; Jia et al., 2015; Kawasaki et al., 2021).

Together, these analyses revealed the presence of epidermal EMP expressing cells and support a hypothesis of ancient homology between zebrafish scales and tetrapod teeth. Furthermore, our observations that SFC express a subset of genes associated with bone development, but also genes encoding EMP proteins, suggest the possibility of a unique calcified matrix, distinct from bone, dentin, or enamel. In humans, odontoblasts and osteoblasts are similarly regulated, form similar collagen-rich ossified matrices and may be capable of transdifferentiating (Kovacs et al., 2021). Similar to mammalian osteoblasts and odontoblasts, SFCs express sp7 and differentiate from runx2a/b+ progenitors (Fig 1A; Fig 2-S1) (Aman et al., 2018; Cox et al., 2018; Iwasaki et al., 2018; Rasmussen et al., 2018). It is likely that of all these cell types are governed by similar fundamental regulatory mechanisms, while specific material properties of the matrices they produce vary as a function of adaptive evolution.

\section{Eda-Edar-NF-kB and thyroid hormone regulate basal epidermal gene expression associated with dermal morphogenesis.}

Eda-Edar-NF-kB signaling plays conserved roles in regulating the patterning and morphogenesis of vertebrate skin appendages (Cui and Schlessinger, 2006; Lefebvre and Mikkola, 2014), whereas thyroid hormone (TH) regulates multiple aspects of skin development and homeostasis (Mancino et al., 2021). Both eda mutants and hypoTH fish completely lack scales at the stage sampled, allowing us to compare transcriptomic signatures and cell type complements associated with scale loss in these different backgrounds (Fig 1A). Analyses of cell type abundance revealed that both scale-free conditions were characterized by a complete lack of fully differentiated dermal SFCs (Fig 3A). These analyses further showed that hypoTH skins lacked all runx2+ dermal SFC progenitors, yet eda mutants-despite homozygosity for a presumptive null allele-retained a small subset of these cells (Fig 3A). We have shown that hypoTH fish lack superficial dermal cell types at the stage sampled for sequencing, though these cell types do appear later in development (Aman et al., 2021). To confirm the presence of residual, pre-SFC in eda mutants, we imaged live fish expressing ET37:EGFP, which enables visualization of all dermal cells (Parinov et al., 2004; Aman et al., 2021). Indeed, eda mutants exhibited a mat of ET37:EGFP+ dermal cells-presumptive pre-SFC-beneath the epidermis that was not present in hypoTH fish (Fig 3B).

To further understand cutaneous roles of $\mathrm{Eda}$ and $\mathrm{TH}$, we examined expression variation for 
genes encoding ligands of major signaling pathways, as these molecules are excellent candidates for effecting epithelial mesenchymal interactions during scale development (Puthiyaveetil et al., 2016). This analysis revealed substantial differences in gene expression, particularly evident in basal epidermal cells of both eda mutants and hypoTH fish compared to the wild-type (Fig 3C,D). Given the common scaleless phenotype but differences in cell type abundance and tissue architecture, we hypothesized that $\mathrm{TH}$ and Eda regulate distinct basal epidermal signaling cues, with TH promoting accumulation of superficial dermal cells and Eda triggering papilla formation and SFC differentiation. Since both processes can be reasonably envisaged to depend on epidermal-derived cues, we focused on signaling ligands expressed by basal epidermal cells. We previously observed that global misexpression of an Fgf ligand rescued scale development in eda mutant fish, and that Edar expression in epidermal cells, but not dermal cells, was sufficient to drive scale formation (Aman et al., 2018). Those results suggested that Eda signaling drives SFC differentiation via epidermal expression of an Fgf ligand. Remarkably, our transcriptomic analysis revealed just a single differentially expressed Fgf ligand gene significantly downregulated in eda mutant basal cells, fgf24 (q-value = 5.49e-28; Fig 3E-G), despite these cells also expressing fgf12a, fgf13a, and fgf18a. Our analyses therefore point to Fgf24 as a likely critical Eda pathway target for scale development.

Since hypoTH basal cells at this stage fail to recruit dermal cells (Aman et al., 2021), we further hypothesized that ligands previously implicated in dermal cell migration would be enriched among hypoTH differentially expressed genes. Closer inspection of differentially expressed signaling ligand genes in basal epidermal cells showed that, indeed, TH promotes expression of pdgfaa, pdgfba, and wnt6b, which encode orthologs of signaling ligands known to recruit dermal cells to epidermis in amniotes (Fig 3H) (Karlsson et al., 1999; Chen et al., 2012). This analysis also suggests several additional signaling ligands as excellent candidates for regulating epidermal signaling to dermal SFC progenitors (Fig 3I).

These observations from scaleless skins suggest that basal epidermal cells are critical targets for both Eda and thyroid hormone, and that epidermally expressed fgf24 is a plausible mechanistic link between Eda signaling and dermal papillae development. Analysis of hypoTH skin revealed $\mathrm{TH}$-dependent transcriptional regulation of paracrine factors implicated in amniote dermal morphogenesis. These findings are of potential clinical significance as pathophysiology underlying TH skin diseases remain unclear (Mancino et al., 2021).

\section{Hypodermal contribution to the stripe-forming pigment cell microenvironment and iridophore differentiation}

Zebrafish pigment pattern is a useful study system for elucidating principles that govern developmental patterning and post-embryonic developmental progression (Patterson and Parichy, 2019). The alternating dark stripes and light interstripes form deep in the skin, which remains remarkably transparent throughout the life of the animal (Fig 1A,B). Stripes include melanophores and sparsely arranged iridescent iridophores, where interstripes comprise densely packed iridophores with overlying yellow-orange xanthophores. Despite being an integral part of the skin and its major visual element, we know little about how these pigment cells interact with other cell types in this microenvironment.

To better define how pigment cells are integrated with other skin cell types and identify tissue environmental factors that may influence pigment patterning, we included in our study the bonaparte mutant, homozygous for a presumptive loss of function mutation in basonuclin 2 (bnc2) (Lang et al., 2009). bnc2 mutants have a very sparse complement of pigment cells as adults owing to reduced numbers of differentiating pigment cells and the progressive death of 
pigment cells during the larva-to-adult transition, with iridophores especially affected (Lang et al., 2009; Patterson and Parichy, 2013).

At the stage of tissue collection, fewer iridophores and melanophores were evident in bnc2 mutants compared to wild-type controls, mirroring prior quantitative comparisons (Fig 4A). Previous analysis of genetic mosaics demonstrated that Bnc2 function is required in the hypodermis for survival and patterning of pigment cells (Lang et al., 2009). Accordingly, we predicted that bnc2 mutants should have substantial differences in gene expression in the hypodermis. Yet alignment of UMAP projections for wild-type and bnc2 mutants also suggested a profound deficiency of hypodermal cells themselves (Fig 4B). We therefore quantified the proportion of various cell types relative to wild-type controls and found marked deficits in hypodermal cells, as well as iridophores, melanophores, and xanthophores, whereas numbers of dermal mesenchyme cells were relatively unchanged (Fig 4C).

Based on these findings, we predicted that hypodermis would be malformed or missing in live bnc2 mutants. To test this prediction and validate inferences from the single cell transcriptome data, we imaged the dermis of live animals expressing ET37:EGFP, expressed broadly across dermal cell types (Aman et al., 2021). In wild-type controls, the hypodermis appeared as a thin, nearly confluent cell layer deep in the dermis, whereas in bnc2 mutants no such layer was apparent, instead the deepest dermis appeared to contain only dermal mesenchyme (Fig 4D; Fig 4 S1A; Fig 1 S1B). Consistent with the hypodermis serving as a pigment cell support population, we observed iridophores, expressing pnp4a:palm-mCherry and melanophores, expressing tyrp1b:palm-mCherry, in close proximity to ET37:EGFP+ hypodermal cells in wild-type skin. These analyses showed that, as predicted, iridophores and melanophores resided in close contact with hypodermal cells in both backgrounds (Fig 4E).

Given the intimate association between wild-type pigment cells and hypodermal cells, together with their stark deficiences in bnc2 mutant fish, we hypothesized that factors important for pigment cell development and patterning are supplied particularly by hypodermal cells, as opposed to other non-pigment cells of the tissue environment (i.e., non-hypodermal stromal cells, developing SFCs, or superficially located muscle progenitor cells, also present in our data set). To test this idea, we examined the expression of genes encoding signaling ligands and adhesion factors implicated previously in pigment pattern development.

These analyses showed that hypodermal cells are likely to be an important driver of iridophore development as they were the principal dermal cells to express endothelin $3 b$ (edn3b) (Fig 4F; Fig 4 S1B), encoding a secreted protein that is processed to an active 21 amino acid peptide required by iridophores. Diminished expression of edn $3 b$ is associated with reduced numbers of iridophores and attenuated interstripes and stripes both in zebrafish mutants and the naturally occurring pattern of $D$. nigrofasciatus (Spiewak et al., 2018). Edn3 acts directly on iridophores, but only indirectly on melanophores through an interaction between these cells and Edn3-dependent iridophores (Parichy et al., 2000; Krauss et al., 2014; Spiewak et al., 2018). Pigment cells themselves expressed edn3b as well, suggesting the possibility of supportive roles in the self-organizing interactions of pigment cells during pattern formation (Patterson and Parichy, 2019).

Roles for hypodermal cells in regulating melanophore development were suggested by expression of other factors, including agouti signaling protein 1 (asip1) (Fig. 4F), which encodes a secreted protein that represses melanophore differentiation in ventral regions of the flank (Cal et al., 2019), though our dataset does not allow us to segment cells spatially. Interestingly, kit ligand a (kitlga), encoding a melanogenic factor that promotes survival, migration, and differentiation, was expressed at only moderate levels by hypodermal cells, despite its broad 
expression in the much simpler skin of embryos and early larvae (Hultman et al., 2007; Budi et al., 2011; Dooley et al., 2013). Nevertheless, kitlga was expressed at higher levels by melanophores themselves, whereas junctional adhesion molecule $3 b$ (jam3b), encoding a 2Immunoglobulin like domain adhesion receptor (Powell and Wright, 2012; Ebnet, 2017), was expressed by both hypodermal cells and melanophores. Jam3b mediates homophilic and heterophilic adhesive interactions, and is required autonomously by melanophores for an adherent phenotype; a Jam3b fusion protein accumulates at sites of overlap between mature melanophores (Eom et al., 2021). In the absence of jam3b function, melanophores tend to be hypopigmented, fail to acquire their mature, well-spread morphology and orderly arrangement, and many die. Together with prior studies, our observations suggest a model in which Jam3b and other factors (Eom et al., 2012) enable interactions between immature melanophores and hypodermis, with hypodermally derived Asip1 helping to maintain the immature state, and subsequent Jam3b-mediated interactions between melanophores promoting terminal maturation and survival in stripes through Kitlga provided by melanophores themselves (Fig 4H).

Our analyses further point to a role for hypodermal cells in regulating xanthophore differentiation. Xanthophores require signaling through Colony stimulating factor-1 receptor-a (Csf1ra) for their migration, survival and differentiation (Parichy and Turner, 2003; Patterson and Parichy, 2013). One source of Csf1 is iridophores, which express csf1a (Fig 4F), and, indeed, xanthophores are at first tightly associated with residual iridophores in bnc2 mutants (Patterson and Parichy, 2013). Nevertheless, xanthophores eventually cover the flank of bnc2 mutants, as well as other iridophore-deficient mutants in which their differentiatation is delayed initially, suggesting an alternative source of Csf1 in the skin. Consistent with this idea we found that hypodermal cells express the csf1a paralogue csf1b (Fig 4F,G,H; Fig 4 S1C), encoding a ligand that is similarly potent to Csf1a in its ability to induce xanthophore differentiation (Parichy et al., 2000; Parichy and Turner, 2003), and melanophores and xanthophores themselves express low levels of Csf1 genes.

Finally, because bnc2 mutants are particularly deficient for iridophores at early stages (Patterson and Parichy, 2013) we asked whether transcriptomic states of these cells are more more severely affected by loss of bnc2 than transcriptomic states of melanophores or xanthophores. Consistent with this idea, we found more differentially expressed genes in iridophores than either xanthophores or melanophores (Fig 4 S1D). This disproportionality may be a consequence of the markedly fewer hypodermal cells and attendant loss of Edn3b or other iridogenic signals. Or, bnc2 may have more pronounced activities within iridophores, as these cells express bnc2, and at levels greater than melanophores or xanthophores (Fig 4F). Though further study will be needed to parse autonomous and non-autonomous (Lang et al., 2009) roles for bnc2 itself, our analyses of gene expression and cell-type abundance identify hypodermal cells as a key source of factors permissive, and possibly instructive, for adult interstripe and stripe development.

\section{Discussion}

Skin is a large, heterogenous and biomedically important organ and the skin of zebrafish is a useful system in which to elucidate mechanisms of skin patterning and morphogenesis. We have generated a minimally biased singe-cell resolution transcriptional atlas of zebrafish skin at a key stage during the larva-to-adult transition during squamation and pigment patterning. These data include transcriptomes for all major epidermal and dermal skin cell types in addition to numerous skin associated cell types including pigment cells. 
Zebrafish is structurally dominated by the scales, thin plates of calcified extracellular material deposited in the skin from dermal papillae that aggregate at the interface of dermis and epidermis. Calcified skin appendages in extant fish are diverse, encompassing various and sundry spines, plates and scales. These forms are composed of extracellular matrices that range from among the hardest material in biology to some of the most flexible (Sire and Huysseune, 2003). We systematically assessed the expression of genes encoding non-collagen calcified matrix proteins throughout the skin during squamation, leading to the discovery of a transcriptionally distinct population of basal epidermal cells that express EMP transcripts, likely corresponding to secretory cells proposed to participate in scale matrix formation based on ultrastructure (Sire et al., 1997). Additionally, the complements of genes expressed by dermal SFC suggests that, although these cells may share a fundamental regulatory machinery with mammalian osteoblasts and odontoblasts including regulation by runx 2 and $s p 7$ transcription factors, they likely produce a unique form of calcified matrix, distinct from bone or dentin. Independent patterning of epidermal EMP-expressing cells and dermal SFCs might underlie some of the morphological diversity among fish skin appendages. For example, it is possible that hard spines, as in pufferfish and armored catfish, are formed by epidermal EMP attached to material deposited by underlying SFC-like cells.

Scales develop from dermal papillae that form under the epidermis. The regulatory underpinnings of scale papillae patterning and morphogenesis depend on signaling interactions, including contributions of Eda-A-Edar-NFkB signaling, that are widely conserved across vertebrate skin appendages (Cui and Schlessinger, 2006; Harris et al., 2008; Aman et al., 2018). Analysis of scale development therefore affords a relatively accessible approach to understanding epithelial mesenchymal signaling interactions that underlie dermal morphogenesis. To this end, we generated and analyzed single cell transcriptomes for two scaleless conditions, eda mutants and hypoTH fish (Harris et al., 2008; McMenamin et al., 2014). Eda is a paracrine factor knows to signal exclusively within the epidermis during squamation and thyroid hormone is an endocrine factor with potential to regulate transcription in any cell (Cui and Schlessinger, 2006; Brent, 2012). Despite widely different spatial ranges over which signals are transmitted, our transcriptomic analysis suggests that both molecules regulate transcription of signaling ligands in basal cells that ultimately affect dermal morphogenesis.

The eponymous striped pattern of zebrafish arises from neural crest derived pigment cells that reside deep within in the skin, beneath the concurrently forming scales (Le Guellec et al., 2004; Hirata et al., 2005), and depends on interactions among all three pigment cell types (Watanabe and Kondo, 2015; Irion et al., 2016; Patterson and Parichy, 2019; Parichy, 2021). Although much has been learned about stripe pattern formation from analysis of mutants lacking one or more pigment cell types, much less is known about how pigment cells integrate into the skin microenvironment. Analyses of genetic mosaics have hinted at an important role for skin cells (Lang et al., 2009; Krauss et al., 2014; Patterson et al., 2014; Eskova et al., 2017); still, this aspect of pigment patterning remains largely unexplored empirically or computationally (Volkening and Sandstede, 2015; Watanabe and Kondo, 2015; Volkening and Sandstede, 2018; Owen et al., 2020). Using single cell transcriptomics and live imaging of wild-type and bnc2 mutant fish, we have identified a discrete population of dermal cells expressing genes that regulate differentiation and morphogenesis of pigment cells, including edn $3 b$, which is required for iridophore population expansion.

Our analyses have focused on scales and pigmentation, however, zebrafish skin is a fruitful study system for many areas of biology including regeneration and wound healing (Richardson et al., 2016; Cox et al., 2018; Iwasaki et al., 2018; Morris et al., 2018; Pfalzgraff et al., 2018); 
innate immunity (Lü et al., 2015; Wurster et al., 2021), stem cell regulation (Lee et al., 2014; Chen et al., 2016; Brock et al., 2019), sensory physiology and developmental neuroscience (Rasmussen et al., 2015; Rasmussen et al., 2018; Peloggia et al., 2021) and human disease modeling (Feitosa et al., 2011; Li et al., 2011). Additionally, considerable insight into general mechanisms of development can emerge from comparing developmental mechanisms across species or between organ system. We expect the transcriptome data presented here to generate useful markers for cross-species comparisons enabling a deeper understanding of the molecular basis of phenotypic evolution.

\section{Methods}

\section{Zebrafish lines and husbandry}

Fish were maintained in the $\mathrm{WT}(\mathrm{ABb})$ background at $28.5^{\circ} \mathrm{C}$. Lines used were Tg(sp7:EGFP)b1212 abbreviated sp7:EGFP (DeLaurier et al., 2010). Et(krt4:EGFP)sqet37 abbreviated ET37:EGFP (Parinov et al., 2004). bnc2utr16e1 (Lang et al., 2009). edadt1261 (Harris et al., 2008). Tg(tg:nVenus-v2a-nfnB) abbreviated tg:Venus-NTR (McMenamin et al., 2014).

Thyroid ablation and rearing hypoTH fish were done as previously described (McMenamin et al., 2014).

Imaging

Alizarin-Red-S vital dye, MS-222 anesthesia and mounting for microscopy as previously described (Aman et al., 2021). Images in Fig 1 - Supp 4B; Fig 2A; Fig 3B; Fig 4A,D,E; Fig 4 Supp 1A were acquired on a Zeiss LSM880 in fast Airyscan mode. Images in Fig 1-Supp 4C, Fig 4A were acquired on a Zeiss LSM880 in conventional confocal mode. Images in Fig 1A, Fig 1 - Supp 4A were acquired on a Zeiss Observer equipped with Yokogawa CSU-X1 spinning disc. Orthogonal views were produced using FIJI (Schindelin et al., 2012). Brightness and contrast were adjusted in Adobe photoshop.

\section{Tissue dissection and storage}

Fish were staged according to (Parichy et al., 2009) and 9.6 SSL individuals were selected for dissection, euthanized with MS-222 and immediately processed. Following removal of the head and fins, skins of wild-type controls, eda homozygotes, bnc2 homozygotes and hypoTH fish in an sp7:EGFP transgenic background zebrafish were removed with forceps and immediately flash frozen in LN2 and stored at $-80^{\circ} \mathrm{C}$ prior to isolation of nuclei $(n=300)$.

\section{Nuclei isolation and sci-RNA-seq2 library preparation}

Separately for each background, frozen skins $(n=\sim 60)$ were thawed over ice in cold lysis buffer (10 mM Tris- $\mathrm{HCl}, \mathrm{pH} 7.4,10 \mathrm{mM} \mathrm{NaCl}, 3 \mathrm{mM} \mathrm{MgCl}$, 0.1\% IGEPAL CA-630) (Cao et al., 2019) supplemented with $5 \%$ Superase RNA Inhibitor and minced with a razorblade until no visible pieces remained $(<1 \mathrm{~min})$. The cell suspension was then pipetted a few times and put through a $50 \mu \mathrm{M}$ filter into $10 \mathrm{~mL}$ of fixation buffer (5\% Paraformaldehyde, 1.25X PBS) (Srivatsan et al., 2020). Nuclei were fixed on ice for 15 minutes then centrifuged at $700 \times g$ for 10 minutes. Fixed nuclei were subsequently rinsed twice with $1 \mathrm{~mL}$ of nuclei resuspension buffer (NSB; (10 mM Tris- $\mathrm{HCl}, \mathrm{pH} 7.4,10 \mathrm{mM} \mathrm{NaCl}, 3 \mathrm{mM} \mathrm{MgCl}$, 1\% Superase RNA Inhibitor, 1\% 0.2mg/mL Ultrapure BSA)), spun down at $750 \times g$ for 6 minutes and incubated in $400 \mu \mathrm{L}$ of permeabilization buffer (NSB $+0.25 \%$ Triton-X) for 3 minutes on ice. Permeabilized nuclei were spun down, resuspended in $400 \mathrm{ul}$ of NSB and sonicated on 'low' for 12 seconds. Following 
sonication, nuclei were spun down once more, resuspended in $400 \mu \mathrm{L}$ of NSB, and nuclei from each sample were DAPI-stained and counted on a hemocytometer. Sci-RNA-seq2 libraries were then prepared as previously described (Cao et al., 2017). Briefly, 1,200 nuclei in $2 \mu \mathrm{L}$ of NSB and $0.25 \mu \mathrm{L}$ of $10 \mathrm{mM}$ dNTP mix (Thermo Fisher Scientific, cat no. R0193) were distributed into each well of 12 96-well plates - 4 per background (LoBind Eppendorf). Then 1 $\mu \mathrm{L}$ of uniquely indexed oligo-dT $(25 \mu \mathrm{M})$ (Cao et al., 2017) was added to every well, incubated at $55 \mathrm{C}$ for 5 minutes and placed on ice. $1.75 \mu \mathrm{L}$ of reverse transcription mix $(1 \mu \mathrm{L}$ of Superscript IV first-strand buffer, $0.25 \mu \mathrm{L}$ of $100 \mathrm{mM}$ DTT, $0.25 \mu \mathrm{L}$ of Superscript IV and $0.25 \mu \mathrm{L}$ of RNAseOUT recombinant ribonuclease inhibitor) was then added to each well and plates incubated at $55^{\circ} \mathrm{C}$ for 10 minutes and placed on ice. Wells were pooled, spun down and resuspended in $500 \mu \mathrm{L}$ NSB and transferred to a flow cytometry tube through a $0.35 \mu \mathrm{m}$ filter cap; DAPI was added to a final concentration of $3 \mu \mathrm{M}$. Pooled nuclei were then sorted on a FACS Aria II cell sorter (BD) at 300 cells per well into 96 well LoBind plates containing $5 \mu \mathrm{L}$ of EB buffer (Qiagen). After sorting, $0.75 \mu \mathrm{L}$ of second strand mix $(0.5 \mu \mathrm{L}$ of mRNA second strand synthesis buffer and $0.25 \mu \mathrm{L}$ of mRNA second strand synthesis enzyme, New England Biolabs) were added to each well, second strand synthesis performed at $16^{\circ} \mathrm{C}$ for 150 minutes. Tagmentation was performed by addition of $5.75 \mu \mathrm{L}$ of tagmentation mix $(0.01 \mu \mathrm{L}$ of a N7-only TDE1 enzyme (in-house) in 5.74 $\mu \mathrm{L} 2 x$ Nextera TD buffer, Illumina) per well and plates incubated for 5 minutes at $55^{\circ} \mathrm{C}$. Reaction was terminated by addition of $12 \mu \mathrm{L}$ of DNA binding buffer (Zymo) and incubated for 5 minutes at room temperature. $36 \mu \mathrm{L}$ of Ampure XP beads were added to every well, DNA purified using the standard Ampure XP clean-up protocol (Beckman Coulter) eluting with $17 \mu \mathrm{L}$ of EB buffer and DNA transferred to a new 96-well LoBind plate. For PCR, $2 \mu \mathrm{L}$ of indexed P5, $2 \mu \mathrm{L}$ of indexed P7 (Cao et al., 2017) and $20 \mu \mathrm{L}$ of NEBNext High-Fidelity master mix (New England Biolabs) were added to each well and PCR performed as follows: $75^{\circ} \mathrm{C}$ for 3 minutes, $98^{\circ} \mathrm{C}$ for 30 seconds and 19 cycles of $98^{\circ} \mathrm{C}$ for 10 seconds, $66^{\circ} \mathrm{C}$ for 30 seconds and $72^{\circ} \mathrm{C}$ for 1 minute followed by a final extension at $72^{\circ} \mathrm{C}$ for 5 minutes. After PCR, all wells were pooled, concentrated using a DNA clean and concentrator kit (Zymo) and purified via an additional 0.8X Ampure XP cleanup. Final library concentrations were determined by Qubit (Invitrogen), libraries visualized using a TapeStation D1000 DNA Screen tape (Agilent) and libraries sequenced on a Nextseq 500 (Illumina) using a high output 75 cycle kit (Read 1: 18 cycles, Read 2: 52 cycles, Index 1: 10 cycles and Index 2: 10 cycles).

\section{Pre-processing of sequencing data}

Sequencing runs were demultiplexed using bcl2fastq v.2.18 and expected PCR barcode combinations. The backbone computational pipeline for read processing was previously published (Cao et al., 2017). Following assignment of RT indices, reads were trimmed using trim-galore and mapped to the zebrafish transcriptome (GRCz11 with extended 3' UTRs) (Saunders et al., 2019) using the STAR aligner (Dobin et al., 2013). Reads were then filtered for alignment quality, and duplicates were removed. Non-duplicate genes were assigned to genes using bedtools (Quinlan and Hall, 2010) to intersect with an annotated gene model. Cell barcodes were considered to represent a real cell if the number of UMIs was greater than 600 , a number chosen based on a user-defined threshold on the knee plot. Cells with greater than 6000 UMls were also discarded as likely multiplets. Reads from cells that passed the UMI thresholds were aggregated into a count matrix and then loaded and saved as a CDS object for downstream analysis with Monocle3 (Cao et al., 2019).

\section{Dimensionality reduction, alignment and background correction}

The wild-type only ( $n=35,114$ ) and all-background (wt, eda, bnc2, hypoTH; $n=144,466)$ CDS 
objects were processed separately. Cells were assigned to their background by matching recovered $\mathrm{RT}$ barcode information to the original plate loadings. For each dataset, the standard monocle3 processing workflow was followed (estimate_size_factors(), detect_genes(), preprocess_cds()) and the top 50 PCs were retained, and PCA was calculated using all genes as input. A few corrections were then made on the original PCA matrix. First, to account for possible cytoplasmic RNAs in the supernatant of each sample that could contribute to "background" in the resulting transcripts assigned to individual cells, we performed a samplespecific background correction as previously described (Packer et al., 2019). Briefly, the background distribution of RNA from was calculated from "cells" that had less than 15 UMIs and used this to compute a "background loading". Next, a linear regression model is fit using these background loadings, real cell PCA matrix cell background loadings, its residuals are considered the "background corrected PCA matrix". This corrected PCA matrix was then subject to Mutual Nearest Neighbor (MNN) alignment (Haghverdi et al., 2018) by sample using the "align_cds" function in monocle3. The background corrected, MNN-aligned PCA matrix was then used as input for Uniform Manifold Approximation and Projection (UMAP) (Becht et al., 2018) dimensionality reduction using the "reduce_dimension" function and default settings (except - umap.min_dist $=0.15$, umap.n_neighbors $=20 \mathrm{~L}$ ). Clustering was performed with "cluster_cells" (wild-type resolution = 2e-4; all-background resolution $=1 \mathrm{e}-4$ ), which uses the Leiden community detection algorithm (Traag et al., 2019). Clustering resolution was manually selected based on clear distinction of non-adjacent groups of cells and a reasonable recovery of overall UMAP structure.

\section{Cell type classification and trajectory analysis}

For each cluster in the wild-type dataset, the most specific genes were calculated using the "top_markers" function. These genes were sorted by specificity and clusters were annotated by comparing genes to published studies and in situ hybridization databases. We assigned 43 clusters to 21 unique cell types and one "unknown" group when the cell type was not able to be determined based on gene expression. To annotate cells from the 3 other backgrounds (eda, bnc2, hypoTH), we built a marker-free cell-type classifier with the wild-type cell annotations using Garnett (Pliner et al., 2019) and applied it to the remaining cells. After cluster extension and manual clean-up of the remaining unannotated or mis-annotated cells, we retained 32 unique cell type annotations across the whole dataset. Trajectory analysis was performed on a sub-setted and re-processed set of cells from the wild-type dermis. These cells form the developing scales and we chose a single stage that contained scale-forming cells along the entire developmental trajectory. After repeating dimensionality reduction, we applied the monocle3 function "learn_graph" and "order_cells" to root the graph and calculate "pseudotime" values for each cell that increased as a function of principal-graph distance from the root.

\section{Analysis of cell type abundance differences}

To compute cell type abundance differences across genotypes, cell counts for each type were normalized by the sample's size factor (the total cell counts from each sample divided by the geometric mean of all sample's total cell counts). The abundance difference was then calculated as $\log _{2}$ (normalized query cell count / normalized reference cell count) for each cell type relative to wild-type for all backgrounds.

\section{Differential expression analysis}

Differentially expressed genes were computed by fitting the size-factor normalized UMI counts 
for each gene from each individual nucleus with a generalized linear model using the "fit_models" function in monocle3. To fit the regression model for each background's effect on each gene in each cell type, we first selected the pair-wise backgrounds and cells that were relevant for the model (i.e. Basal cells from wild-type and eda). Then we filtered for genes expressed in at least 10 cells, and used background as the model formula (model_formula_str = " genotype") and extracted the coefficient table, p-values and multiple testing corrected qvalues with the "coefficient_table" function. Genes were considered significantly backgrounddependent differentially expressed (DEGs) if their q-value was less than 0.05 . For analysis of specific pathways, we used $D$. rerio gene-pathway associations from WikiPathways (Martens et al., 2021).

\section{Acknowledgements}

Supported by the NIH R35 GM122471 to DMP and NIH 1U54HL145611, NIH UM1HG011586, and NIH R01 HG010632 to CT as well as funding from the Paul G. Allen Frontiers foundation (Allen Discovery Center) to CT. Thanks to Amber Schwindling and other Parichy lab members for assistance with fish care. 


\section{References}

Aman AJ, Fulbright AN, Parichy DM. 2018. Wnt/beta-catenin regulates an ancient signaling network during zebrafish scale development. Elife 7. doi: 10.7554/eLife.37001, PMID: 30014845

Aman AJ, Kim M, Saunders LM, Parichy DM. 2021. Thyroid hormone regulates abrupt skin morphogenesis during zebrafish postembryonic development. bioRxiv:2021.04.09.439217. doi:10.1101/2021.04.09.439217,

Aman AJ, Parichy DM. Chapter 8 - Zebrafish Integumentary System. In: Cartner SC, Eisen JS, Farmer SC, Guillemin KJ, Kent ML, Sanders GE, editors. The Zebrafish in Biomedical Research: Academic Press; 2020. p. 91-6.

Ayoola AO, Zhang BL, Meisel RP, Nneji LM, Shao Y, Morenikeji OB, Adeola AC, Ng'ang'a SI, Ogunjemite BG, Okeyoyin AO, Roos C, Wu DD. 2021. Population Genomics Reveals Incipient Speciation, Introgression, and Adaptation in the African Mona Monkey (Cercopithecus mona). Mol Biol Evol 38:876-90. doi: 10.1093/molbev/msaa248, PMID: 32986826

Bae JM, Clarke JC, Rashid H, Adhami MD, McCullough K, Scott JS, Chen H, Sinha KM, de Crombrugghe B, Javed A. 2018. Specificity Protein 7 Is Required for Proliferation and Differentiation of Ameloblasts and Odontoblasts. J Bone Miner Res 33:1126-40. doi: 10.1002/jbmr.3401, PMID: 29405385

Becht E, Mclnnes L, Healy J, Dutertre CA, Kwok IWH, Ng LG, Ginhoux F, Newell EW. 2018. Dimensionality reduction for visualizing single-cell data using UMAP. Nat Biotechnol. doi: 10.1038/nbt.4314, PMID: 30531897

Braasch I, Gehrke AR, Smith JJ, Kawasaki K, Manousaki T, Pasquier J, Amores A, Desvignes T, Batzel P, Catchen J, Berlin AM, Campbell MS, Barrell D, Martin KJ, Mulley JF, Ravi V, Lee AP, Nakamura T, Chalopin D, Fan S, Wcisel D, Cañestro C, Sydes J, Beaudry FEG, Sun Y, Hertel J, Beam MJ, Fasold M, Ishiyama M, Johnson J, Kehr S, Lara M, Letaw JH, Litman GW, Litman RT, Mikami M, Ota T, Saha NR, Williams L, Stadler PF, Wang H, Taylor JS, Fontenot Q, Ferrara A, Searle SMJ, Aken B, Yandell M, Schneider I, Yoder JA, Volff J-N, Meyer A, Amemiya CT, Venkatesh B, Holland PWH, Guiguen Y, Bobe J, Shubin NH, Di Palma F, Alföldi J, Lindblad-Toh $\mathrm{K}$, Postlethwait JH. 2016. The spotted gar genome illuminates vertebrate evolution and facilitates human-teleost comparisons. Nature genetics 48:427-37. doi: 10.1038/ng.3526, PMID: 26950095

Brent GA. 2012. Mechanisms of thyroid hormone action. The Journal of Clinical Investigation 122:3035-43. doi: 10.1172/JCl60047,

Brock CK, Wallin ST, Ruiz OE, Samms KM, Mandal A, Sumner EA, Eisenhoffer GT. 2019. Stem cell proliferation is induced by apoptotic bodies from dying cells during epithelial tissue maintenance. Nature Communications 10:1044. doi: 10.1038/s41467-019-09010-6,

Budi EH, Patterson LB, Parichy DM. 2011. Post-embryonic nerve-associated precursors to adult pigment cells: genetic requirements and dynamics of morphogenesis and differentiation. PLoS Genet 7:e1002044. doi: 10.1371/journal.pgen.1002044, PMID: 21625562

Cal L, Suarez-Bregua P, Comesana P, Owen J, Braasch I, Kelsh R, Cerda-Reverter JM, Rotllant J. 2019. Countershading in zebrafish results from an Asip1 controlled dorsoventral gradient of pigment cell differentiation. Scientific reports 9:3449. doi: 10.1038/s41598-019-40251-z, PMID: 30837630

Cao J, Packer JS, Ramani V, Cusanovich DA, Huynh C, Daza R, Qiu X, Lee C, Furlan SN, Steemers FJ, Adey A, Waterston RH, Trapnell C, Shendure J. 2017. Comprehensive single-cell transcriptional profiling of a multicellular organism. Science 357:661-7. doi:

10.1126/science.aam8940, PMID: 28818938

Cao J, Spielmann M, Qiu X, Huang X, Ibrahim DM, Hill AJ, Zhang F, Mundlos S, Christiansen L, Steemers FJ, Trapnell C, Shendure J. 2019. The single-cell transcriptional landscape of mammalian organogenesis. Nature 566:496-502. doi: 10.1038/s41586-019-0969-x, PMID: 30787437 
Chen CF, Foley J, Tang PC, Li A, Jiang TX, Wu P, Widelitz RB, Chuong CM. 2015. Development, regeneration, and evolution of feathers. Annu Rev Anim Biosci 3:169-95. doi: 10.1146/annurevanimal-022513-114127, PMID: 25387232

Chen CH, Puliafito A, Cox BD, Primo L, Fang Y, Di Talia S, Poss KD. 2016. Multicolor Cell Barcoding Technology for Long-Term Surveillance of Epithelial Regeneration in Zebrafish. Dev Cell 36:668-80. doi: 10.1016/j.devcel.2016.02.017, PMID: 27003938

Chen D, Jarrell A, Guo C, Lang R, Atit R. 2012. Dermal $\beta$-catenin activity in response to epidermal Wnt ligands is required for fibroblast proliferation and hair follicle initiation. Development 139:1522-33. doi: 10.1242/dev.076463,

Cluzeau C, Hadj-Rabia S, Jambou M, Mansour S, Guigue P, Masmoudi S, Bal E, Chassaing N, Vincent MC, Viot G, Clauss F, Maniere MC, Toupenay S, Le Merrer M, Lyonnet S, Cormier-Daire V, Amiel J, Faivre L, de Prost Y, Munnich A, Bonnefont JP, Bodemer C, Smahi A. 2011. Only four genes (EDA1, EDAR, EDARADD, and WNT10A) account for $90 \%$ of hypohidrotic/anhidrotic ectodermal dysplasia cases. Hum Mutat 32:70-2. doi: 10.1002/humu.21384, PMID: 20979233

Cox BD, De Simone A, Tornini VA, Singh SP, Di Talia S, Poss KD. 2018. In Toto Imaging of Dynamic Osteoblast Behaviors in Regenerating Skeletal Bone. Curr Biol 28:3937-47 e4. doi: 10.1016/j.cub.2018.10.052, PMID: 30503623

Cui CY, Schlessinger D. 2006. EDA signaling and skin appendage development. Cell Cycle 5:247783. doi: 10.4161/cc.5.21.3403, PMID: 17102627

DaSilva-Arnold SC, Kuo C-Y, Davra V, Remache Y, Kim PCW, Fisher JP, Zamudio S, Al-Khan A, Birge RB, Illsley NP. 2019. ZEB2, a master regulator of the epithelial-mesenchymal transition, mediates trophoblast differentiation. Mol Hum Reprod 25:61-75. doi: 10.1093/molehr/gay053, PMID: 30462321

De Simone A, Evanitsky MN, Hayden L, Cox BD, Wang J, Tornini VA, Ou J, Chao A, Poss KD, Di Talia S. 2021. Control of osteoblast regeneration by a train of Erk activity waves. Nature 590:129-33. doi: 10.1038/s41586-020-03085-8, PMID: 33408418

DeLaurier A, Eames BF, Blanco-Sanchez B, Peng G, He X, Swartz ME, Ullmann B, Westerfield M, Kimmel CB. 2010. Zebrafish sp7:EGFP: a transgenic for studying otic vesicle formation, skeletogenesis, and bone regeneration. Genesis 48:505-11. doi: 10.1002/dvg.20639, PMID: 20506187

Di-Poï N, Milinkovitch MC. 2016. The anatomical placode in reptile scale morphogenesis indicates shared ancestry among skin appendages in amniotes. Science Advances 2. doi: 10.1126/sciadv. 1600708 ,

Dobin A, Davis CA, Schlesinger F, Drenkow J, Zaleski C, Jha S, Batut P, Chaisson M, Gingeras TR. 2013. STAR: ultrafast universal RNA-seq aligner. Bioinformatics (Oxford, England) 29:15-21. doi: 10.1093/bioinformatics/bts635, PMID: 23104886

Dooley CM, Mongera A, Walderich B, Nusslein-Volhard C. 2013. On the embryonic origin of adult melanophores: the role of ErbB and Kit signalling in establishing melanophore stem cells in zebrafish. Development 140:1003-13. doi: 10.1242/dev.087007, PMID: 23364329

Duverger O, Morasso MI. 2009. Epidermal patterning and induction of different hair types during mouse embryonic development. Birth Defects Res C Embryo Today 87:263-72. doi: 10.1002/bdrc.20158, PMID: 19750518

Ebnet K. 2017. Junctional Adhesion Molecules (JAMs): Cell Adhesion Receptors With Pleiotropic Functions in Cell Physiology and Development. Physiol Rev 97:1529-54. doi: 10.1152/physrev.00004.2017, PMID: 28931565

Endo C, Johnson TA, Morino R, Nakazono K, Kamitsuji S, Akita M, Kawajiri M, Yamasaki T, Kami A, Hoshi Y, Tada A, Ishikawa K, Hine M, Kobayashi M, Kurume N, Tsunemi Y, Kamatani N, Kawashima M. 2018. Genome-wide association study in Japanese females identifies fifteen novel skin-related trait associations. Scientific reports 8:8974. doi: 10.1038/s41598-018-27145-2, PMID: 29895819 
Eom DS, Inoue S, Patterson LB, Gordon TN, Slingwine R, Kondo S, Watanabe M, Parichy DM. 2012. Melanophore migration and survival during zebrafish adult pigment stripe development require the immunoglobulin superfamily adhesion molecule Igsf11. PLoS Genet 8:e1002899. doi: 10.1371/journal.pgen.1002899, PMID: 22916035

Eom DS, Patterson LB, Bostic RR, Parichy DM. 2021. Immunoglobulin superfamily receptor Junctional adhesion molecule 3 (Jam3) requirement for melanophore survival and patterning during formation of zebrafish stripes. bioRxiv:2021.03.01.433381. doi: 10.1101/2021.03.01.433381,

Eskova A, Chauvigné F, Maischein H-M, Ammelburg M, Cerdà J, Nüsslein-Volhard C, Irion U. 2017. Gain-of-function mutations in Aqp3a influence zebrafish pigment pattern formation through the tissue environment. Development (Cambridge, England) 144:2059-69. doi: 10.1242/dev.143495, PMID: 28506994

Feitosa NM, Richardson R, Bloch W, Hammerschmidt M. 2011. Basement membrane diseases in zebrafish. Methods Cell Biol 105:191-222. doi: 10.1016/b978-0-12-381320-6.00008-4, PMID: 21951531

Francescangeli F, Contavalli P, De Angelis ML, Careccia S, Signore M, Haas TL, Salaris F, Baiocchi M, Boe A, Giuliani A, Tcheremenskaia O, Pagliuca A, Guardiola O, Minchiotti G, Colace L, Ciardi A, D'Andrea V, La Torre F, Medema J, De Maria R, Zeuner A. 2020. A pre-existing population of ZEB2+ quiescent cells with stemness and mesenchymal features dictate chemoresistance in colorectal cancer. Journal of Experimental \& Clinical Cancer Research 39:2. doi: 10.1186/s13046-019-1505-4,

Haghverdi L, Lun ATL, Morgan MD, Marioni JC. 2018. Batch effects in single-cell RNA-sequencing data are corrected by matching mutual nearest neighbors. Nat Biotechnol 36:421-7. doi: 10.1038/nbt.4091, PMID: 29608177

Harris MP, Rohner N, Schwarz H, Perathoner S, Konstantinidis P, Nüsslein-Volhard C. 2008. Zebrafish eda and edar Mutants Reveal Conserved and Ancestral Roles of Ectodysplasin Signaling in Vertebrates. PLoS Genet 4:e1000206. doi: 10.1371/journal.pgen.1000206,

Hegarty SV, Sullivan AM, O'Keeffe GW. 2015. Zeb2: A multifunctional regulator of nervous system development. Progress in neurobiology 132:81-95. doi: 10.1016/j.pneurobio.2015.07.001, PMID: 26193487

Hessle L, Stordalen GA, Wenglén C, Petzold C, Tanner EK, Brorson S-H, Baekkevold ES, Önnerfjord P, Reinholt FP, Heinegård D. 2013. The Skeletal Phenotype of Chondroadherin Deficient Mice. PLOS ONE 8:e63080. doi: 10.1371/journal.pone.0063080,

Hirata M, Nakamura K-I, Kondo S. 2005. Pigment cell distributions in different tissues of the zebrafish, with special reference to the striped pigment pattern. Developmental Dynamics 234:293-300. doi: 10.1002/dvdy.20513,

Houghton L, Lindon C, Morgan BA. 2005. The ectodysplasin pathway in feather tract development. Development 132:863-72. doi: 10.1242/dev.01651,

Hultman KA, Bahary N, Zon LI, Johnson SL. 2007. Gene Duplication of the zebrafish kit ligand and partitioning of melanocyte development functions to kit ligand a. PLoS Genet 3:e17. doi: 06PLGE-RA-0401R2 [pii] 10.1371/journal.pgen.0030017, PMID: 17257055

Irion U, Singh AP, Nusslein-Volhard C. 2016. The Developmental Genetics of Vertebrate Color Pattern Formation: Lessons from Zebrafish. Curr Top Dev Biol 117:141-69. doi: 10.1016/bs.ctdb.2015.12.012, PMID: 26969976

Iwasaki M, Kuroda J, Kawakami K, Wada H. 2018. Epidermal regulation of bone morphogenesis through the development and regeneration of osteoblasts in the zebrafish scale. Dev Biol. doi: 10.1016/j.ydbio.2018.03.005, PMID: 29524434

Jia J, Bian Z, Song Y. 2015. Dspp mutations disrupt mineralization homeostasis during odontoblast differentiation. Am J Transl Res 7:2379-96. PMID: 26807185 
Jussila M, Thesleff I. 2012. Signaling Networks Regulating Tooth Organogenesis and Regeneration, and the Specification of Dental Mesenchymal and Epithelial Cell Lineages. Cold Spring Harbor Perspectives in Biology 4. doi: 10.1101/cshperspect.a008425,

Karlsson L, Bondjers C, Betsholtz C. 1999. Roles for PDGF-A and sonic hedgehog in development of mesenchymal components of the hair follicle. Development 126:2611-21. doi: 10.1242/dev.126.12.2611,

Kawasaki K. 2009. The SCPP gene repertoire in bony vertebrates and graded differences in mineralized tissues. Development Genes and Evolution 219:147-57. doi: 10.1007/s00427-0090276-x,

Kawasaki K. 2011. The SCPP gene family and the complexity of hard tissues in vertebrates. Cells, tissues, organs 194:108-12. doi: 10.1159/000324225, PMID: 21576905

Kawasaki K, Keating JN, Nakatomi M, Welten M, Mikami M, Sasagawa I, Puttick MN, Donoghue PCJ, Ishiyama M. 2021. Coevolution of enamel, ganoin, enameloid, and their matrix SCPP genes in osteichthyans. iScience 24:102023. doi: 10.1016/j.isci.2020.102023, PMID: 33506188

Kere J, Srivastava AK, Montonen O, Zonana J, Thomas N, Ferguson B, Munoz F, Morgan D, Clarke A, Baybayan P, Chen EY, Ezer S, Saarialho-Kere U, de la Chapelle A, Schlessinger D. 1996. Xlinked anhidrotic (hypohidrotic) ectodermal dysplasia is caused by mutation in a novel transmembrane protein. Nat Genet 13:409-16. doi: 10.1038/ng0895-409, PMID: 8696334

Kondo S, Kuwahara Y, Kondo M, Naruse K, Mitani H, Wakamatsu Y, Ozato K, Asakawa S, Shimizu N, Shima A. 2001. The medaka rs-3 locus required for scale development encodes ectodysplasin-A receptor. Current Biology 11:1202-6. doi: h10.1016/S0960-9822(01)00324-4

Kovacs CS, Chaussain C, Osdoby P, Brandi ML, Clarke B, Thakker RV. 2021. The role of biomineralization in disorders of skeletal development and tooth formation. Nature Reviews Endocrinology. doi: 10.1038/s41574-021-00488-z,

Krauss J, Frohnhöfer HG, Walderich B, Maischein H-M, Weiler C, Irion U, Nüsslein-Volhard C. 2014. Endothelin signalling in iridophore development and stripe pattern formation of zebrafish. Biology Open 3:503-9. doi: 10.1242/bio.20148441,

Lang MR, Patterson LB, Gordon TN, Johnson SL, Parichy DM. 2009. Basonuclin-2 requirements for zebrafish adult pigment pattern development and female fertility. PLoS Genet 5:e1000744. doi: 10.1371/journal.pgen.1000744, PMID: 19956727

Larsson T, Sommarin Y, Paulsson M, Antonsson P, Hedbom E, Wendel M, Heinegård D. 1991. Cartilage matrix proteins. A basic $36-\mathrm{kDa}$ protein with a restricted distribution to cartilage and bone. J Biol Chem 266:20428-33. PMID: 1939097

Le Guellec D, Morvan-Dubois G, Sire JY. 2004. Skin development in bony fish with particular emphasis on collagen deposition in the dermis of the zebrafish (Danio rerio). Int J Dev Biol 48:217-31. doi: 10.1387/ijdb.031768dg

Lee RT, Asharani PV, Carney TJ. 2014. Basal keratinocytes contribute to all strata of the adult zebrafish epidermis. PLoS One 9:e84858. doi: 10.1371/journal.pone.0084858, PMID: 24400120

Lefebvre S, Mikkola ML. 2014. Ectodysplasin research--where to next? Semin Immunol 26:220-8. doi: 10.1016/j.smim.2014.05.002, PMID: 24928340

Li Q, Frank M, Thisse CI, Thisse BV, Uitto J. 2011. Zebrafish: a model system to study heritable skin diseases. J Invest Dermatol 131:565-71. doi: 10.1038/jid.2010.388, PMID: 21191402

Lü AJ, Hu XC, Wang Y, Zhu AH, Shen LL, Tian J, Feng ZZ, Feng ZJ. 2015. Skin immune response in the zebrafish, Danio rerio (Hamilton), to Aeromonas hydrophila infection: a transcriptional profiling approach. J Fish Dis 38:137-50. doi: 10.1111/jfd.12214, PMID: 24517469

MacDougall M, Gu TT, Simmons D. 1996. Dentin matrix protein-1, a candidate gene for dentinogenesis imperfecta. Connect Tissue Res 35:267-72. doi: 10.3109/03008209609029200, PMID: 9084665

Mancino G, Miro C, Di Cicco E, Dentice M. 2021. Thyroid hormone action in epidermal development and homeostasis and its implications in the pathophysiology of the skin. Journal of Endocrinological Investigation. doi: 10.1007/s40618-020-01492-2 
Märss T. 2006. Exoskeletal ultrasculpture of early vertebrates. Journal of Vertebrate Paleontology 26:235-52. doi: 10.1671/0272-4634(2006)26[235:EUOEV]2.0.CO;2,

Martens M, Ammar A, Riutta A, Waagmeester A, Slenter DN, Hanspers K, R AM, Digles D, Lopes EN, Ehrhart F, Dupuis LJ, Winckers LA, Coort SL, Willighagen EL, Evelo CT, Pico AR, Kutmon M. 2021. WikiPathways: connecting communities. Nucleic Acids Res 49:D613-d21. doi: 10.1093/nar/gkaa1024, PMID: 33211851

McMenamin SK, Bain EJ, McCann AE, Patterson LB, Eom DS, Waller ZP, Hamill JC, Kuhlman JA, Eisen JS, Parichy DM. 2014. Thyroid hormone-dependent adult pigment cell lineage and pattern in zebrafish. Science 345:1358-61. doi: 10.1126/science.1256251, PMID: 25170046

Metz JR, de Vrieze E, Lock E-J, Schulten IE, Flik G. 2012. Elasmoid scales of fishes as model in biomedical bone research. Journal of Applied Ichthyology 28:382-7. doi: 10.1111/j.14390426.2012.01990.x

Mongera A, Nüsslein-Volhard C. 2013. Scales of fish arise from mesoderm. Current Biology 23:R338-R9. doi: 10.1016/j.cub.2013.02.056.

Morris JL, Cross SJ, Lu Y, Kadler KE, Lu Y, Dallas SL, Martin P. 2018. Live imaging of collagen deposition during skin development and repair in a collagen I - GFP fusion transgenic zebrafish line. Developmental biology 441:4-11. doi: 10.1016/j.ydbio.2018.06.001, PMID: 29883658

Owen JP, Kelsh RN, Yates CA. 2020. A quantitative modelling approach to zebrafish pigment pattern formation. eLife 9:e52998. doi: 10.7554/eLife.52998,

Packer JS, Zhu Q, Huynh C, Sivaramakrishnan P, Preston E, Dueck H, Stefanik D, Tan K, Trapnell C, Kim J, Waterston RH, Murray JI. 2019. A lineage-resolved molecular atlas of C. elegans embryogenesis at single-cell resolution. Science 365. doi: 10.1126/science.aax1971, PMID: 31488706

Parichy DM. 2021. Evolution of pigment cells and patterns: recent insights from teleost fishes. Curr Opin Genet Dev 69:88-96. doi: 10.1016/j.gde.2021.02.006, PMID: 33743392

Parichy DM, Elizondo MR, Mills MG, Gordon TN, Engeszer RE. 2009. Normal table of postembryonic zebrafish development: Staging by externally visible anatomy of the living fish. Developmental Dynamics 238:2975-3015. doi: 10.1002/dvdy.22113,

Parichy DM, Mellgren EM, Rawls JF, Lopes SS, Kelsh RN, Johnson SL. 2000. Mutational analysis of endothelin receptor b1 (rose) during neural crest and pigment pattern development in the zebrafish Danio rerio. Dev Biol 227:294-306. doi: 10.1006/dbio.2000.9899, PMID: 11071756

Parichy DM, Ransom DG, Paw B, Zon LI, Johnson SL. 2000. An orthologue of the kit-related gene $\mathrm{fms}$ is required for development of neural crest-derived xanthophores and a subpopulation of adult melanocytes in the zebrafish, Danio rerio. Development 127:3031-44. PMID: 10862741

Parichy DM, Turner JM. 2003. Temporal and cellular requirements for Fms signaling during zebrafish adult pigment pattern development. Development 130:817-33. PMID: 12538511

Parinov S, Kondrichin I, Korzh V, Emelyanov A. 2004. Tol2 transposon-mediated enhancer trap to identify developmentally regulated zebrafish genes in vivo. Dev Dyn 231:449-59. doi: 10.1002/dvdy.20157, PMID: 15366023

Patterson LB, Bain EJ, Parichy DM. 2014. Pigment cell interactions and differential xanthophore recruitment underlying zebrafish stripe reiteration and Danio pattern evolution. Nat Commun 5:5299. doi: 10.1038/ncomms6299, PMID: 25374113

Patterson LB, Parichy DM. 2013. Interactions with iridophores and the tissue environment required for patterning melanophores and xanthophores during zebrafish adult pigment stripe formation. PLoS Genet 9:e1003561. doi: 10.1371/journal.pgen.1003561, PMID: 23737760

Patterson LB, Parichy DM. 2019. Zebrafish Pigment Pattern Formation: Insights into the Development and Evolution of Adult Form. Annual Review of Genetics 53:505-30. doi: 10.1146/annurev-genet-112618-043741,

Peloggia J, Münch D, Meneses-Giles P, Romero-Carvajal A, Lush ME, Lawson ND, McClain M, Pan YA, Piotrowski T. 2021. Adaptive cell invasion maintains lateral line organ homeostasis in response to environmental changes. Developmental Cell. doi: 10.1016/j.devcel.2021.03.027 
Pfalzgraff A, Barcena-Varela S, Heinbockel L, Gutsmann T, Brandenburg K, Martinez-de-Tejada G, Weindl G. 2018. Antimicrobial endotoxin-neutralizing peptides promote keratinocyte migration via P2X7 receptor activation and accelerate wound healing in vivo. Br J Pharmacol 175:3581-93. doi: 10.1111/bph.14425, PMID: 29947028

Pliner HA, Shendure J, Trapnell C. 2019. Supervised classification enables rapid annotation of cell atlases. Nat Methods 16:983-6. doi: 10.1038/s41592-019-0535-3, PMID: 31501545

Powell GT, Wright GJ. 2012. Genomic organisation, embryonic expression and biochemical interactions of the zebrafish junctional adhesion molecule family of receptors. PLOS ONE 7:e40810. doi: 10.1371/journal.pone.0040810, PMID: 22815827

Puthiyaveetil JSV, Kota K, Chakkarayan R, Chakkarayan J, Thodiyil AKP. 2016. Epithelial Mesenchymal Interactions in Tooth Development and the Significant Role of Growth Factors and Genes with Emphasis on Mesenchyme - A Review. J Clin Diagn Res 10:ZE05-ZE9. doi: 10.7860/JCDR/2016/21719.8502, PMID: 27790596

Quan H, Yang W, Lapeyriere M, Schaible E, Ritchie RO, Meyers MA. 2020. Structure and Mechanical Adaptability of a Modern Elasmoid Fish Scale from the Common Carp. Matter 3:84263. doi: 10.1016/j.matt.2020.05.011

Quinlan AR, Hall IM. 2010. BEDTools: a flexible suite of utilities for comparing genomic features. Bioinformatics 26:841-2. doi: 10.1093/bioinformatics/btq033, PMID: 20110278

Raouf A, Ganss B, McMahon C, Vary C, Roughley PJ, Seth A. 2002. Lumican is a major proteoglycan component of the bone matrix. Matrix Biol 21:361-7. doi: 10.1016/s0945053x(02)00027-6, PMID: 12128073

Rasmussen JP, Sack GS, Martin SM, Sagasti A. 2015. Vertebrate epidermal cells are broadspecificity phagocytes that clear sensory axon debris. J Neurosci 35:559-70. doi: 10.1523/jneurosci.3613-14.2015, PMID: 25589751

Rasmussen JP, Vo NT, Sagasti A. 2018. Fish Scales Dictate the Pattern of Adult Skin Innervation and Vascularization. Dev Cell 46:344-59 e4. doi: 10.1016/j.devcel.2018.06.019, PMID: 30032992

Rasouly HM, Kumar S, Chan S, Pisarek-Horowitz A, Sharma R, Xi QJ, Nishizaki Y, Higashi Y, Salant DJ, Maas RL, Lu W. 2016. Loss of Zeb2 in mesenchyme-derived nephrons causes primary glomerulocystic disease. Kidney international 90:1262-73. doi: 10.1016/j.kint.2016.06.037, PMID: 27591083

Richardson R, Metzger M, Knyphausen P, Ramezani T, Slanchev K, Kraus C, Schmelzer E, Hammerschmidt M. 2016. Re-epithelialization of cutaneous wounds in adult zebrafish combines mechanisms of wound closure in embryonic and adult mammals. Development 143:2077-88. doi: 10.1242/dev.130492, PMID: 27122176

Rosset EM, Bradshaw AD. 2016. SPARC/osteonectin in mineralized tissue. Matrix Biol 52-54:78-87. doi: 10.1016/j.matbio.2016.02.001, PMID: 26851678

Saunders LM, Mishra AK, Aman AJ, Lewis VM, Toomey MB, Packer JS, Qiu X, McFaline-Figueroa JL, Corbo JC, Trapnell C, Parichy DM. 2019. Thyroid hormone regulates distinct paths to maturation in pigment cell lineages. eLife 8:e45181. doi: 10.7554/eLife.45181, PMID: 31140974

Schindelin J, Arganda-Carreras I, Frise E, Kaynig V, Longair M, Pietzsch T, Preibisch S, Rueden C, Saalfeld S, Schmid B, Tinevez J-Y, White DJ, Hartenstein V, Eliceiri K, Tomancak P, Cardona A. 2012. Fiji: an open-source platform for biological-image analysis. Nature Methods 9:676-82. doi: 10.1038/nmeth.2019,

Shimada A, Kawanishi T, Kaneko T, Yoshihara H, Yano T, Inohaya K, Kinoshita M, Kamei Y, Tamura K, Takeda H. 2013. Trunk exoskeleton in teleosts is mesodermal in origin. Nature Communications 4:1639. doi: 10.1038/ncomms2643

Sire J-Y, Allizard F, Babiar O, Bourguignon J, Quilhac A. 1997. Scale development in zebrafish (Danio rerio). Journal of Anatomy 190:545-61. doi: 10.1046/j.1469-7580.1997.19040545.x, PMID: PMC1467640 
Sire J-Y, Donoghue PCJ, Vickaryous MK. 2009. Origin and evolution of the integumentary skeleton in non-tetrapod vertebrates. Journal of Anatomy 214:409-40. doi: 10.1111/j.14697580.2009.01046.x,

Sire JY. 1990. From Ganoid to Elasmoid Scales in the Acinopterygian Fishes. Netherlands Journal of Zoology 40:75-92. doi: 10.1163/156854289X00192

Sire JY, Akimenko MA. 2004. Scale development in fish: a review, with description of sonic hedgehog (shh) expression in the zebrafish (Danio rerio). Int J Dev Biol 48:233-47. PMID: 15272389

Sire JY, Huysseune A. 2003. Formation of dermal skeletal and dental tissues in fish: a comparative and evolutionary approach. Biol Rev Camb Philos Soc 78:219-49. PMID: 12803422

Sire JY, Quilhac A, Bourguignon J, Allizard F. 1997. Evidence for participation of the epidermis in the deposition of superficial layer of scales in zebrafish (Danio rerio): A SEM and TEM study. $J$ Morphol 231:161-74. doi: 10.1002/(sici)1097-4687(199702)231:2<161::aid-jmor5>3.0.co;2-h, PMID: 29852665

Smith MP, Donoghue PCJ, Sansom IJ. 2002. The spatial and temporal diversification of Early Palaeozoic vertebrates. Geological Society, London, Special Publications 194:69-83. doi: 10.1144/gsl.sp.2002.194.01.06,

Spiewak JE, Bain EJ, Liu J, Kou K, Sturiale SL, Patterson LB, Diba P, Eisen JS, Braasch I, Ganz J, Parichy DM. 2018. Evolution of Endothelin signaling and diversification of adult pigment pattern in Danio fishes. PLOS Genetics 14:e1007538. doi: 10.1371/journal.pgen.1007538,

Srivastava AK, Pispa J, Hartung AJ, Du Y, Ezer S, Jenks T, Shimada T, Pekkanen M, Mikkola ML, Ko MS, Thesleff I, Kere J, Schlessinger D. 1997. The Tabby phenotype is caused by mutation in a mouse homologue of the EDA gene that reveals novel mouse and human exons and encodes a protein (ectodysplasin-A) with collagenous domains. Proc Natl Acad Sci U S A 94:13069-74. PMID: 9371801

Srivatsan SR, McFaline-Figueroa JL, Ramani V, Saunders L, Cao J, Packer J, Pliner HA, Jackson DL, Daza RM, Christiansen L, Zhang F, Steemers F, Shendure J, Trapnell C. 2020. Massively multiplex chemical transcriptomics at single-cell resolution. Science 367:45-51. doi: 10.1126/science.aax6234, PMID: 31806696

Thomas G, Moffatt P, Salois P, Gaumond MH, Gingras R, Godin E, Miao D, Goltzman D, Lanctôt C. 2003. Osteocrin, a novel bone-specific secreted protein that modulates the osteoblast phenotype. J Biol Chem 278:50563-71. doi: 10.1074/jbc.M307310200, PMID: 14523025

Traag VA, Waltman L, van Eck NJ. 2019. From Louvain to Leiden: guaranteeing well-connected communities. Scientific reports 9:5233. doi: 10.1038/s41598-019-41695-Z, PMID: 30914743

Venkatesh B, Lee AP, Ravi V, Maurya AK, Lian MM, Swann JB, Ohta Y, Flajnik MF, Sutoh Y, Kasahara M, Hoon S, Gangu V, Roy SW, Irimia M, Korzh V, Kondrychyn I, Lim ZW, Tay BH, Tohari S, Kong KW, Ho S, Lorente-Galdos B, Quilez J, Marques-Bonet T, Raney BJ, Ingham PW, Tay A, Hillier LW, Minx P, Boehm T, Wilson RK, Brenner S, Warren WC. 2014. Elephant shark genome provides unique insights into gnathostome evolution. Nature 505:174-9. doi: 10.1038/nature12826, PMID: 24402279

Visser M, Palstra R-J, Kayser M. 2014. Human skin color is influenced by an intergenic DNA polymorphism regulating transcription of the nearby BNC2 pigmentation gene. Human Molecular Genetics 23:5750-62. doi: 10.1093/hmg/ddu289,

Volkening A, Sandstede B. 2015. Modelling stripe formation in zebrafish: an agent-based approach. Journal of The Royal Society Interface 12:20150812. doi: doi:10.1098/rsif.2015.0812,

Volkening A, Sandstede B. 2018. Iridophores as a source of robustness in zebrafish stripes and variability in Danio patterns. Nat Commun 9:3231. doi: 10.1038/s41467-018-05629-z, PMID: 30104716

Watanabe M, Kondo S. 2015. Is pigment patterning in fish skin determined by the Turing mechanism? Trends Genet 31:88-96. doi: 10.1016/j.tig.2014.11.005, PMID: 25544713 
Wolock SL, Lopez R, Klein AM. 2019. Scrublet: Computational Identification of Cell Doublets in Single-Cell Transcriptomic Data. Cell systems 8:281-91.e9. doi: 10.1016/j.cels.2018.11.005, PMID: 30954476

Wurster S, Ruiz OE, Samms KM, Tatara AM, Albert ND, Kahan PH, Nguyen AT, Mikos AG, Kontoyiannis DP, Eisenhoffer GT. 2021. EGF-mediated suppression of cell extrusion during mucosal damage attenuates opportunistic fungal invasion. Cell Reports 34:108896. doi: 10.1016/j.celrep.2021.108896,

Zhang C. 2012. Molecular mechanisms of osteoblast-specific transcription factor Osterix effect on bone formation. Beijing Da Xue Xue Bao Yi Xue Ban 44:659-65. PMID: 23073571 
Figure 1. A whole-skin single cell transcriptome from zebrafish undergoing skin patterning. (A) Brightfield image showing the stiped pigment pattern and confocal image of the same fish to visualize scale forming cells (SFC) expressing sp7:EGFP. At 9.6 SSL, approximately three weeks post fertilization under standard conditions, zebrafish are developing a striped pigment pattern of alternating dark melanophores and iridescent iridophores. Wt individuals with precisely four rows of scale were selected for nuclei preparation. Scaleless eda mutants and hypoTH fish were selected based on standard length. (B) Schematic representation of zebrafish skin at 9.6 SSL. The dark melanophores, yellow xanthophores and iridescent iridophores (colored circles) organize into alternating stripes underneath the dermal layer in which SFCs differentiate (yellow, red). The epidermis (blue) is the outermost layer pf the skin. The posterior margin of each scale integrates into the epidermis (lavender). (C) UMAP visualization of 35,114 wild-type transcriptomes, colored by cell type assignment inferred by marker gene enrichment. Colors correspond to the schematic in (B). Pigment cells include xanthophores (yellow), melanophores (black), and iridophores (blue). SFC, Scale forming cell. Scale bar: A, $500 \mu \mathrm{m}$.
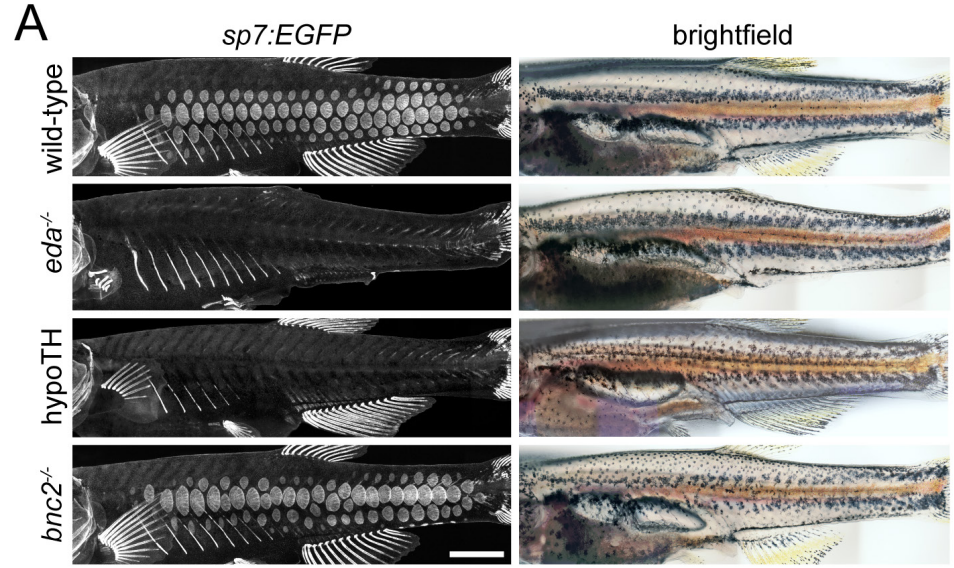

B

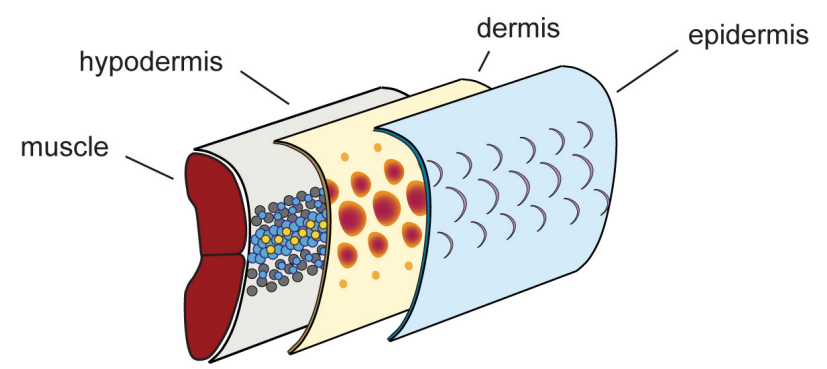

C

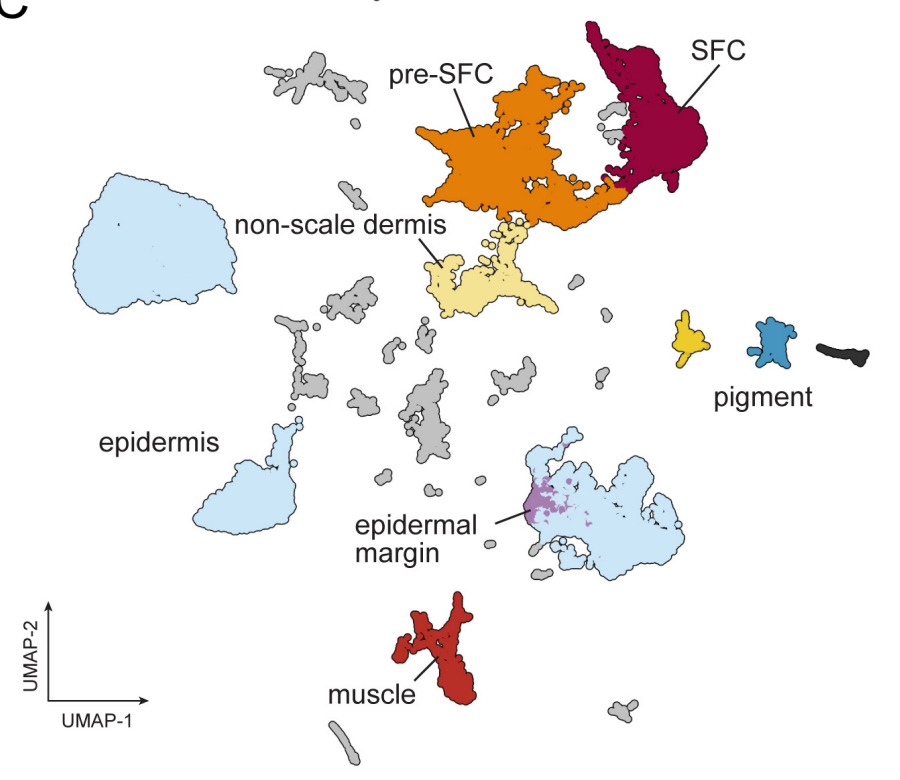


bioRxiv preprint doi: https://doi.org/10.1101/2021.05.12.443782; this version posted May 13, 2021. The copyright holder for this preprint (which

was not certified by peer review) is the author/funder, who has granted bioRxiv a license to display the preprint in perpetuity. It is made available under aCC-BY-NC-ND 4.0 International license.

Figure 1 - Supplement 1. Post-embryonic skin morphogenesis. (A) Overview of dermal development visualized by imaging ET37:EGFP transgenics, which label most dermal cells. Fish were selected for skin dissection when they had four rows of scales (day3). (B) Development of an individual scale. (C) Pigment pattern reiteration occurs during the same timeframe, with secondary interstripe initiation occurring at the sampled stage. (hyp, hypodermis; dm, dermal mesenchyme; mel, melanophore.) Scale bars: A, $1 \mathrm{~mm} ; \mathrm{B}, 10 \mu \mathrm{m} ; \mathrm{C}, 500 \mu \mathrm{M}$.
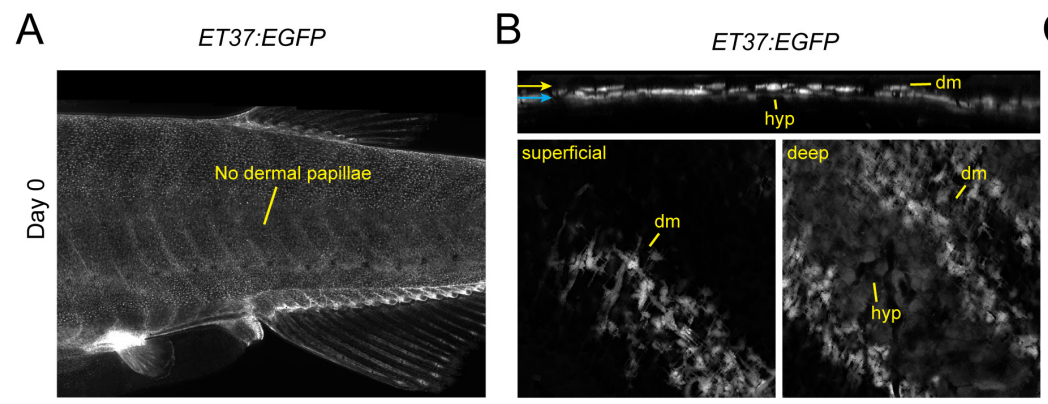

C pnp4a:palm-mCherry
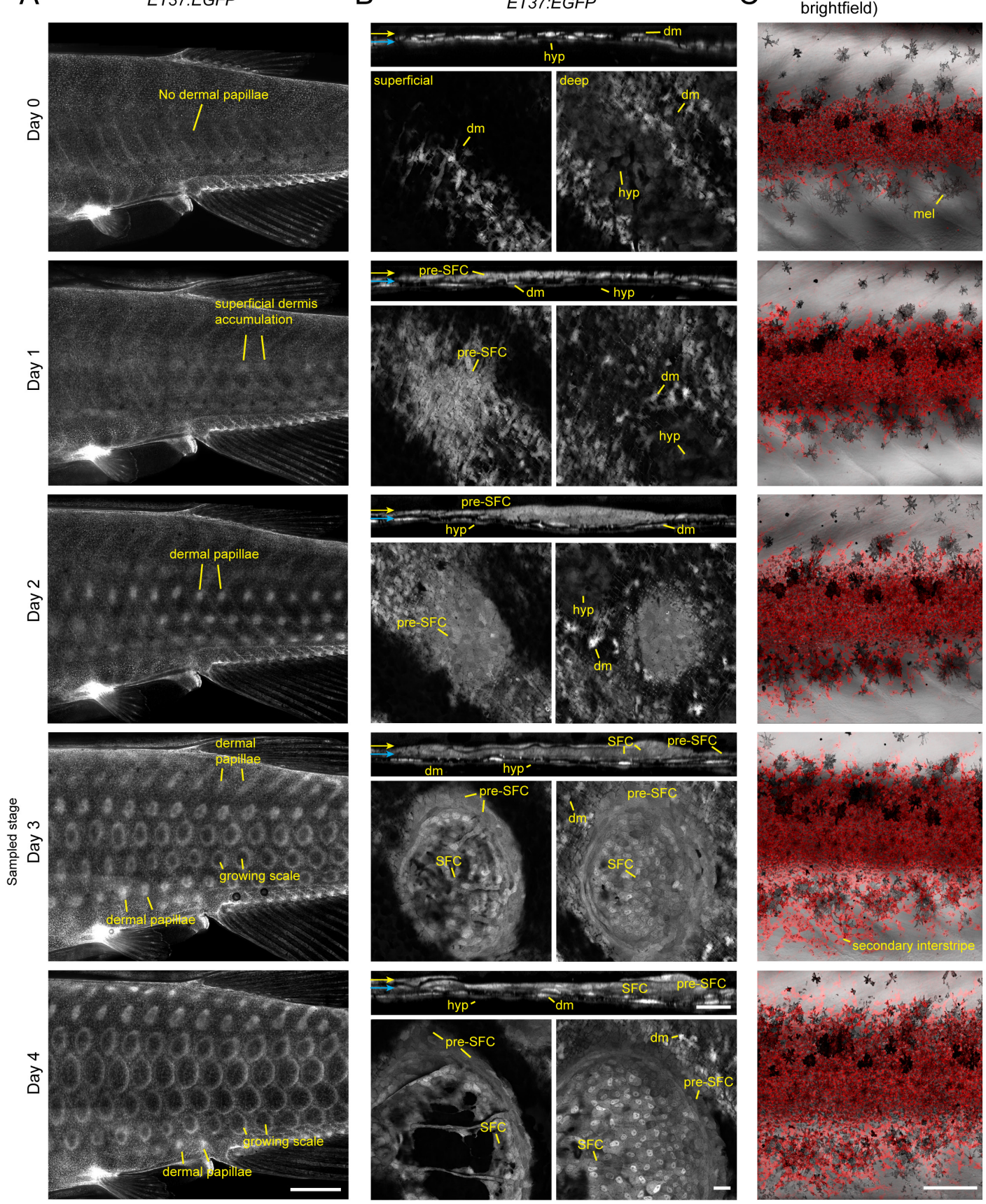
Figure 1 - Supplement 2. sci-RNA-seq data quality metrics across backgrounds. $(A, B)$ Counts of unique molecular identifiers (UMIs) and unique genes expressed across annotated cell types (shown are medians with boxes spanning interquartile ranges; vertical lines indicate farthest observations of data with outlier samples shown individually). (C) A UMAP plot with cells from all genetic backgrounds, colored by cell type annotation and major groups labelled ( $n=144,466$ cells). (D) The same UMAP plot as (C) with cells colored by their genetic background of origin (wild-type, eda-/-, hypoTH, and bnc2-/-). (E) Recovered cell counts from each genetic background and boxplots displaying UMI counts across backgrounds. (F) Cell type percentages across backgrounds. Colors correspond to cell types in $(\mathrm{C})$.

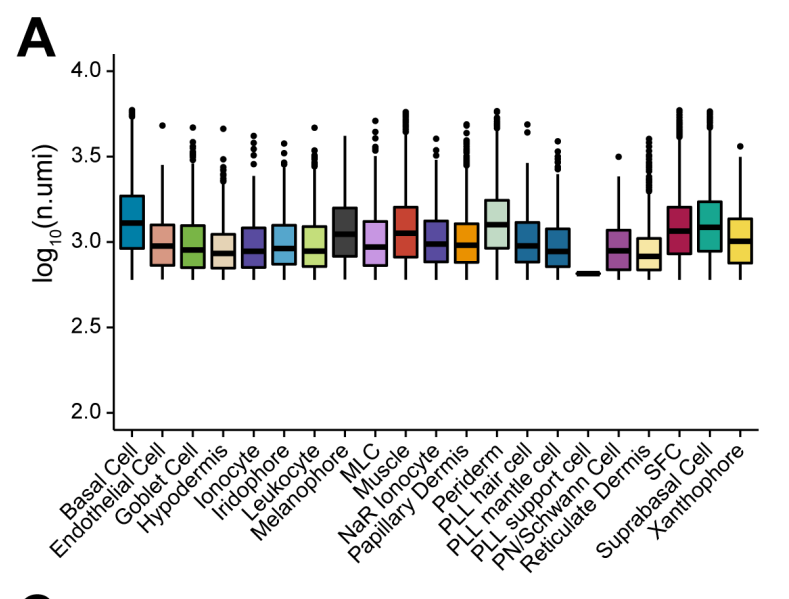

C
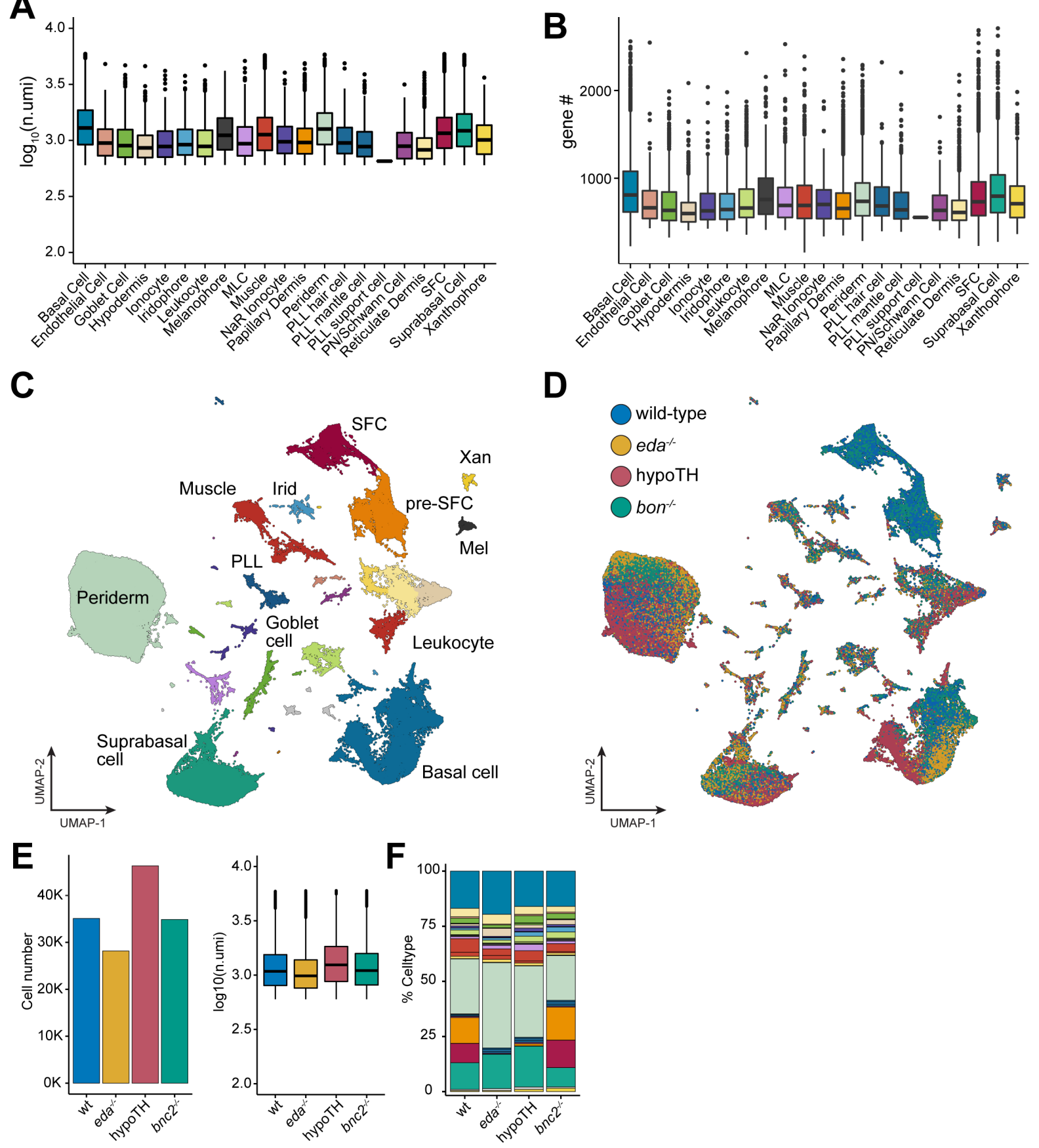
bioRxiv preprint doi: https://doi.org/10.1101/2021.05.12.443782; this version posted May 13, 2021. The copyright holder for this preprint (which

was not certified by peer review) is the author/funder, who has granted bioRxiv a license to display the preprint in perpetuity. It is made available under aCC-BY-NC-ND 4.0 International license.

Figure 1 - Supplement 3. A transcriptome atlas of major cell types in post-embryonic skin. (A) Wild-type cells, colored and labelled by all 22 annotated cell types (cell $n=35,114$ cells). (B) Dot-plot heatmap displaying known cell type marker genes and new candidate markers.

A

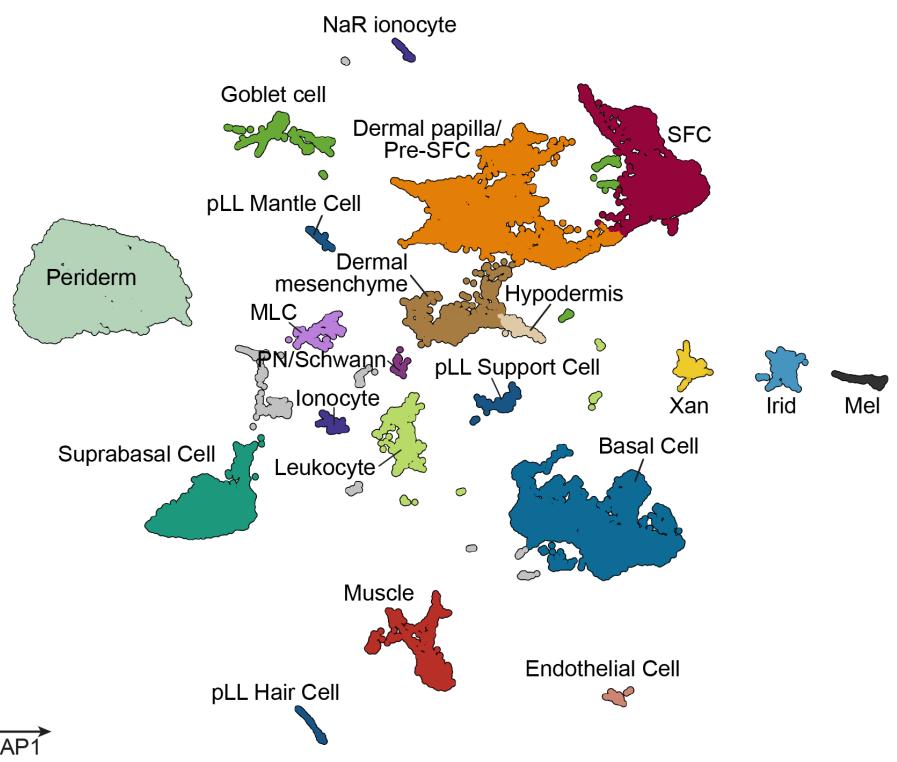

B

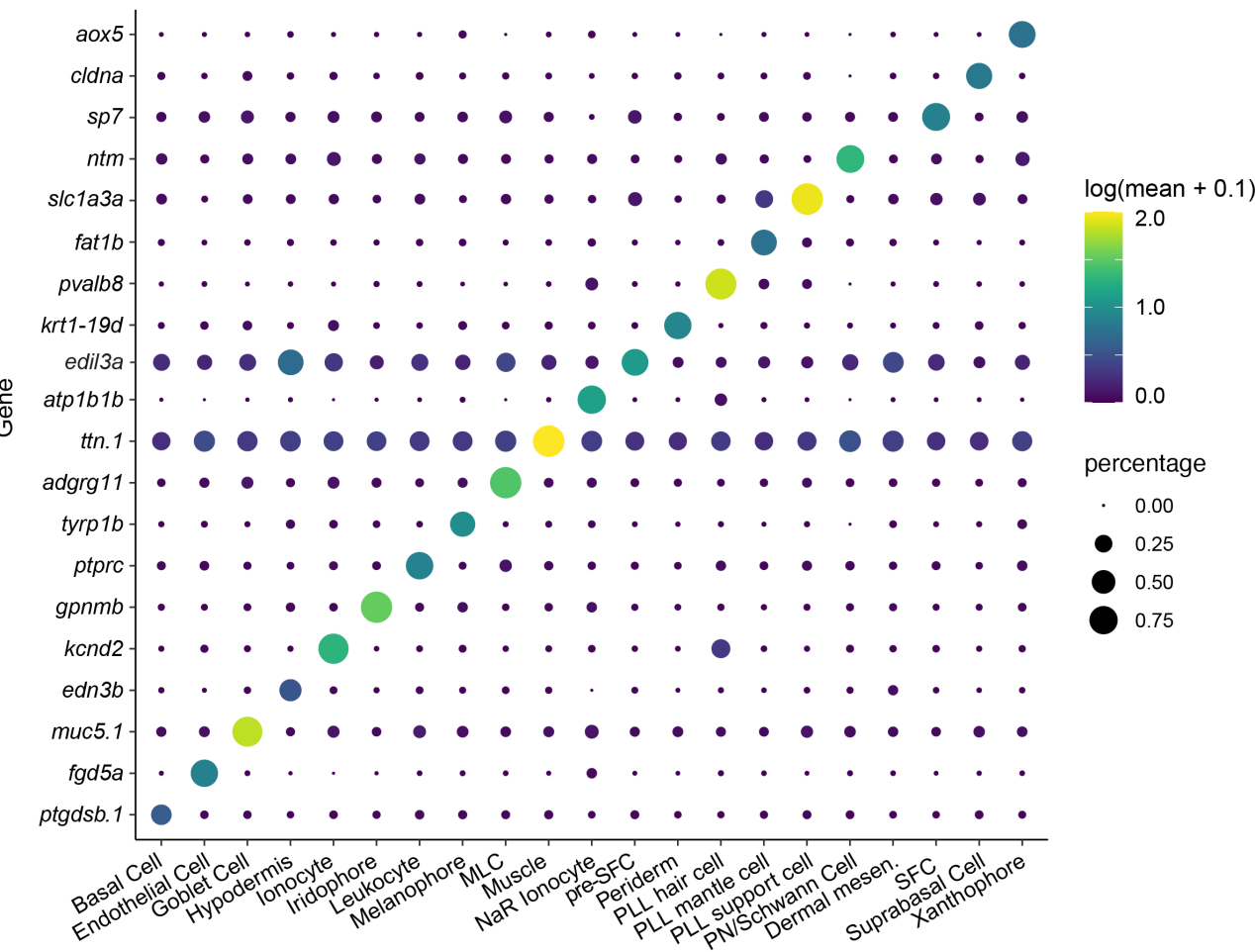


bioRxiv preprint doi: https://doi.org/10.1101/2021.05.12.443782; this version posted May 13, 2021. The copyright holder for this preprint (which

was not certified by peer review) is the author/funder, who has granted bioRxiv a license to display the preprint in perpetuity. It is made available under aCC-BY-NC-ND 4.0 International license.

Figure 2. Non-collagen calcified matrix transcripts are expressed in both dermal SFCs and a subset of basal epidermal cells. (A) Live imaging of the calcified matrix of the scale plate, stained with Alizarin-Red S (magenta). Upper panel shows a cross-sectional view corresponding to position of the dashed line in the lower panel, which shows a lateral view. The scale plate is partially wrapped by dermal cells visualized by ET37:EGFP fluorescence (green), but the superficial surface of the plate is free from dermal cells. (B) UMAP visualization of subclustered SFC and basal epidermal cells. (C) Dot plot visualization of transcripts encoding non-collagen calcified matrix proteins across SFC and Basal cells. ambn, an enamaloid associated transcript, is expressed in a basal cell subpopulation. (D,E) UMAP visualization for ambn and spp1 showing expression in transcriptionally distinct subclusters of basal cells and SFCs, respectively (arrows). Scale bar: A, $10 \mu \mathrm{m}$.

A

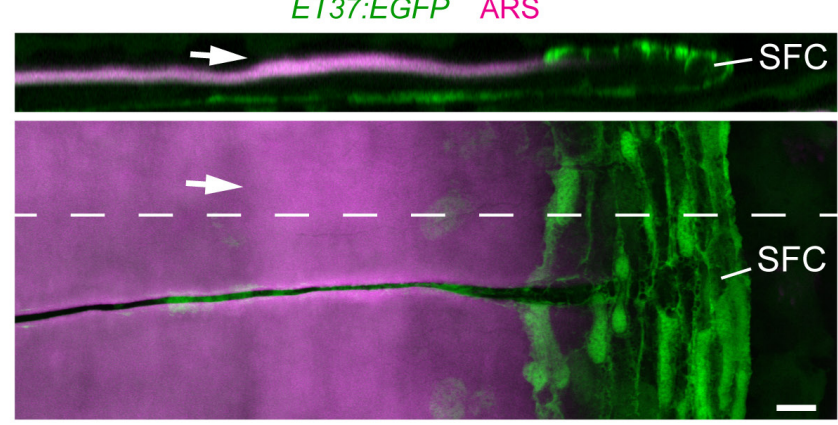

C

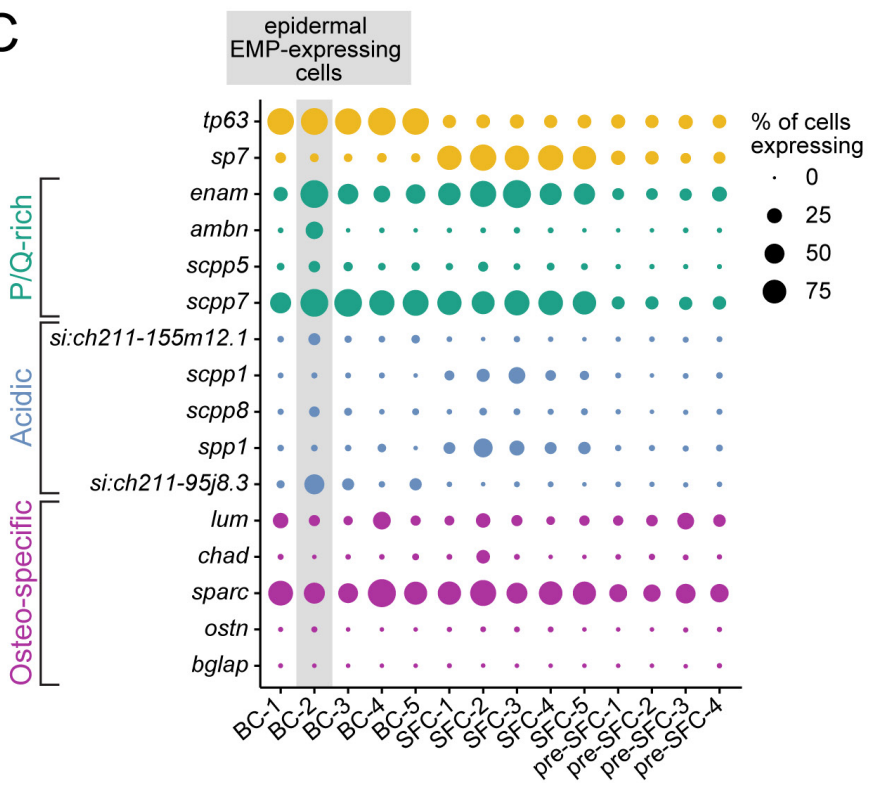

B

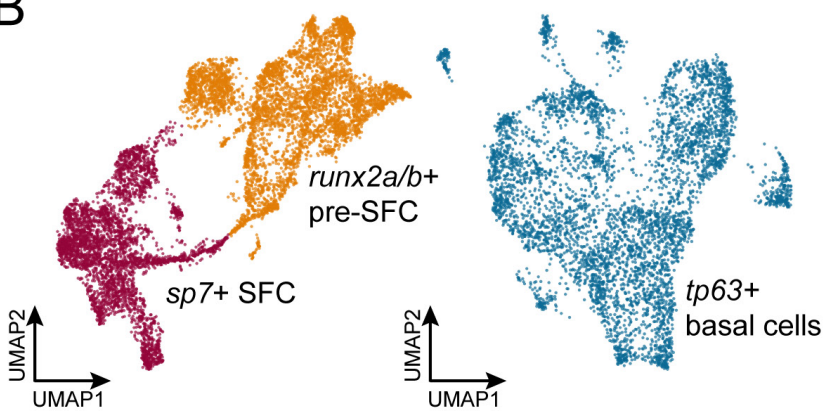

D $a m b n$

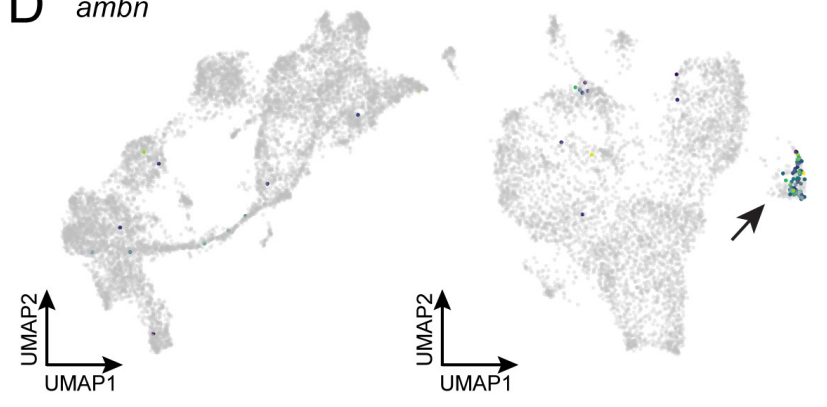

E
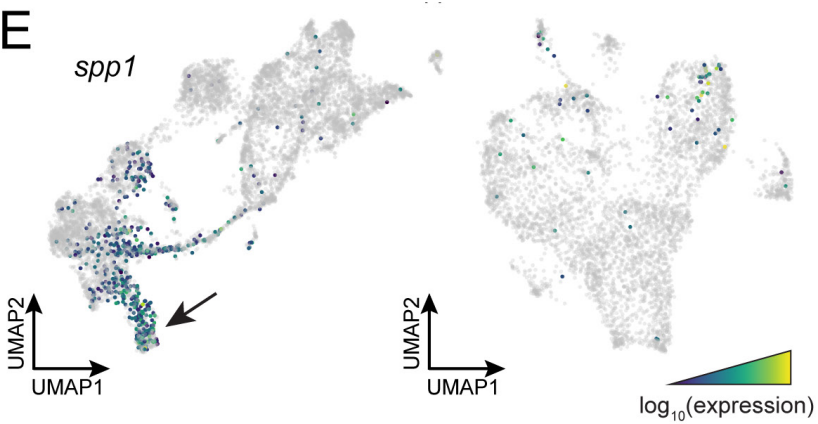
bioRxiv preprint doi: https://doi.org/10.1101/2021.05.12.443782; this version posted May 13, 2021. The copyright holder for this preprint (which

was not certified by peer review) is the author/funder, who has granted bioRxiv a license to display the preprint in perpetuity. It is made available under aCC-BY-NC-ND 4.0 International license.

Figure 2 - Supplement 1. Basal cell and SFC sub-clustering and scale trajectory analysis. (A) Sub-clustered SFC and Basal cell UMAP plots. Numbers correspond to the x-axis in Fig 2C. (B) Relative expression level of key marker genes as a function of pseudotime. zeb2 regulates mesenchymal progenitors in a variety of contexts (Hegarty et al., 2015; Rasouly et al., 2016; DaSilva-Arnold et al., 2019; Francescangeli et al., 2020). runx2 and sp7 regulate differentiation of amniote osteoblasts and odontoblasts (Jussila and Thesleff, 2012; Zhang, 2012; Bae et al., 2018). spp1 encodes a non-collagen calcified matrix protein associated with bone (Kawasaki, 2009). (C) SFC UMAP plot colored by pseudotime.

A

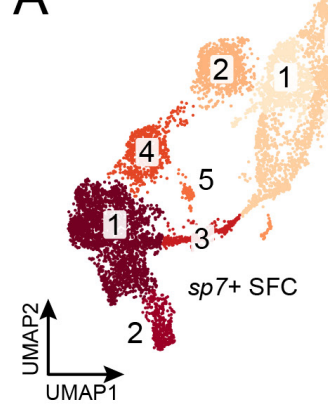

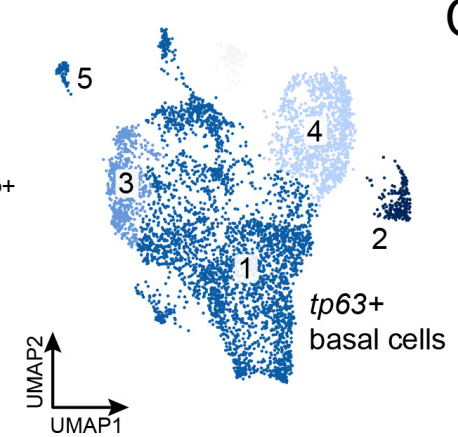

B
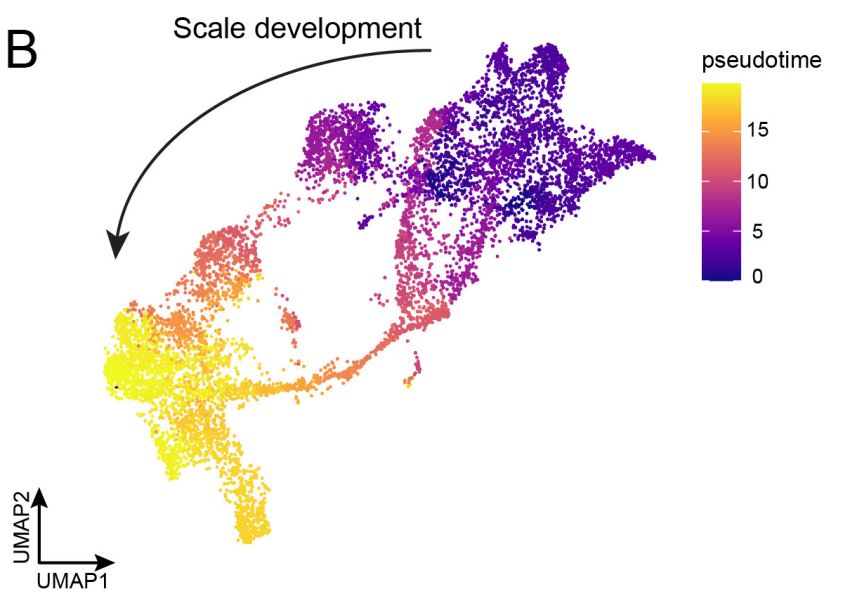

C

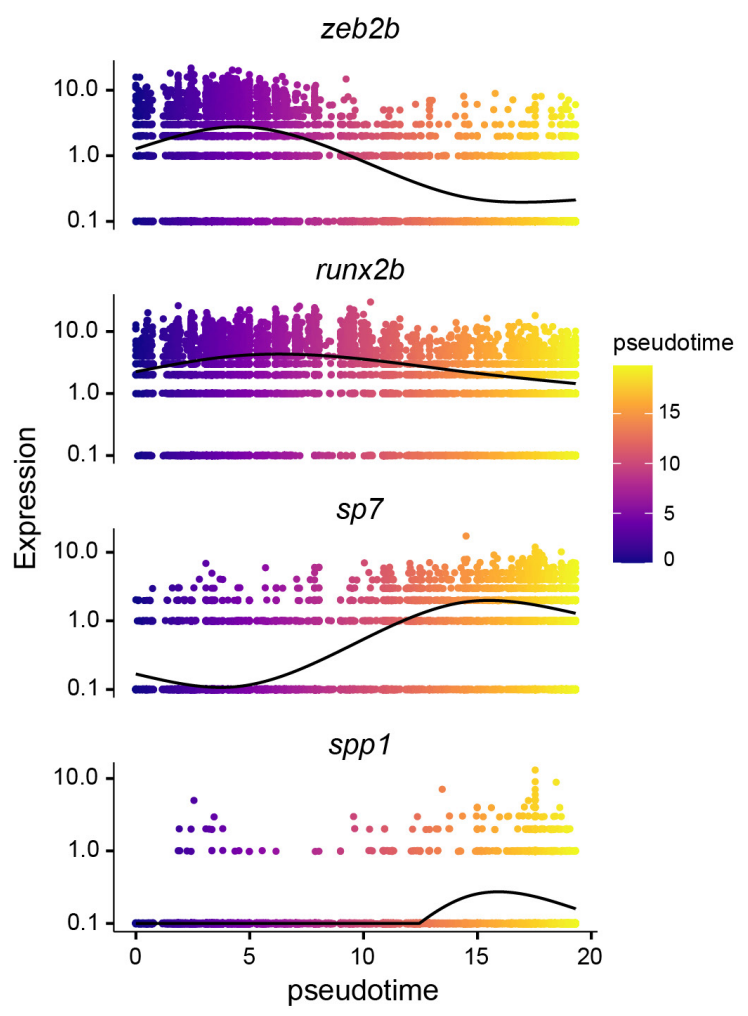


Figure 3. Eda and thyroid hormone regulate signaling ligand transcription in basal epidermal cells. (A) UMAP visualization with wild-type cells in blue, eda mutant cells in yellow and hypoTH cells in red highlighting the absence of SFC and pre-SFC. Heatmap visualization of cell type abundance shows that eda mutants retain more pre-SFCs than hypoTH fish (abundance change measured as $\log _{2}$ (normalized query cell type / normalized wt cell type), see Methods for normalization procedure). (B) Optical sections of wild-type, eda mutant and hypoTH dermis showing a dominant presence of SFC in wt, thin layer of pre-SFC in eda mutants, and lack of pre-SFC in hypoTH skin. dm, dermal mesenchyme; h, hypodermis. (C,D) Heatmap visualization of major pathway signaling ligands that are significantly differentially expressed in (C) eda mutants and (D) hypoTH skin relative to wild-type ( $q$-values $<0.05)$. Cell types not represented lacked significantly differentially expressed signaling ligands in these pathways. (E) Histogram representing the number of ligands in the marked signaling pathways significantly downregulated in eda mutant and hypoTH basal epidermal cells. (F) fgf24 expression was detected in a significantly smaller fraction of eda mutant and hypoTH basal epidermal cells than in wild-type ( $q$-value $=5.49 \mathrm{e}-28$, estimate $=2.36$ ). (G) UMAP visualization of fgf24 expression in wild-type and eda mutants. $(\mathrm{H})$ Eda and TH regulate expression of dermogenic signaling ligands in basal cells ( $q$-value $<1 \mathrm{e}-20$; ${ }^{* * *}$ ). (I) TH hormone regulates expression of a host of paracrine factors in basal cells. These ligands are downregulated in hypoTH skin relative to wild-type ( $q$-value $<0.05)$. Scale bar: A, $10 \mu \mathrm{m}$.

Figure 3 appears on the next page 
bioRxiv preprint doi: https://doi.org/10.1101/2021.05.12.443782; this version posted May 13, 2021. The copyright holder for this preprint (which was not certified by peer review) is the author/funder, who has granted bioRxiv a license to display the preprint in perpetuity. It is made available under aCC-BY-NC-ND 4.0 International license.

\section{Figure 3}
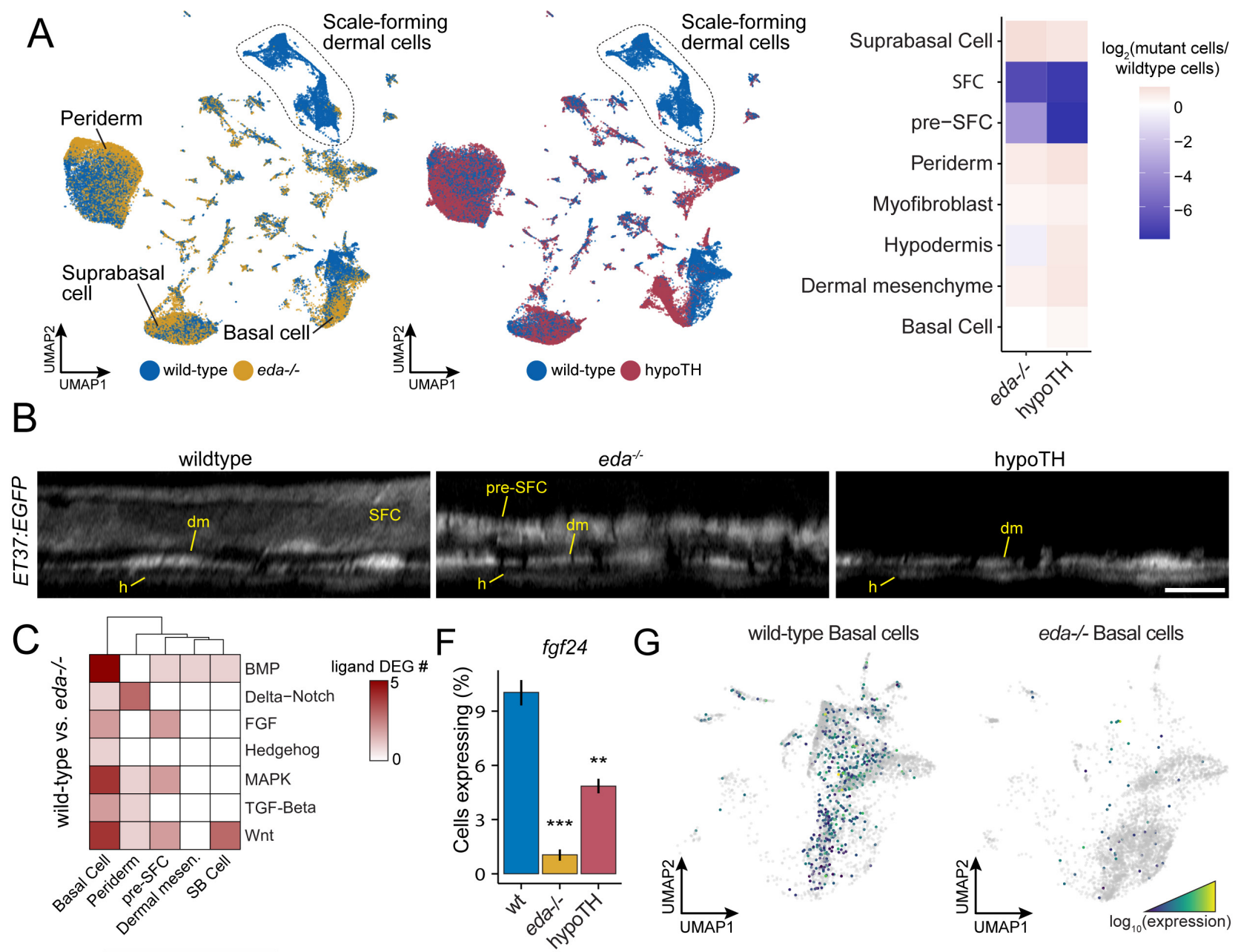

G wild-type Basal cells

eda-/-Basal cells

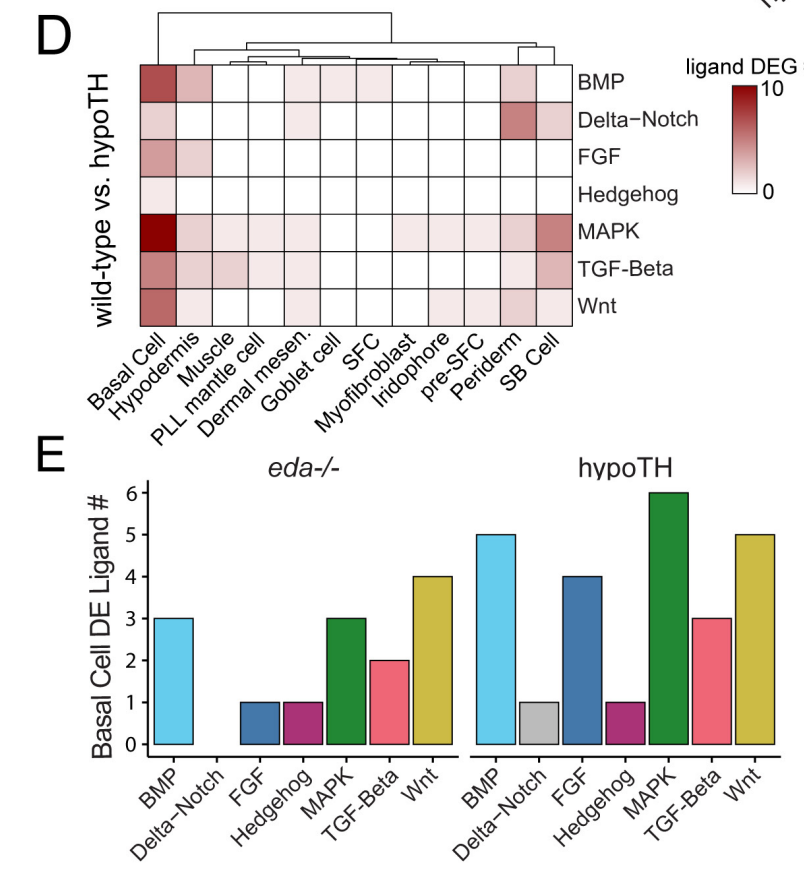

$\mathrm{H}$
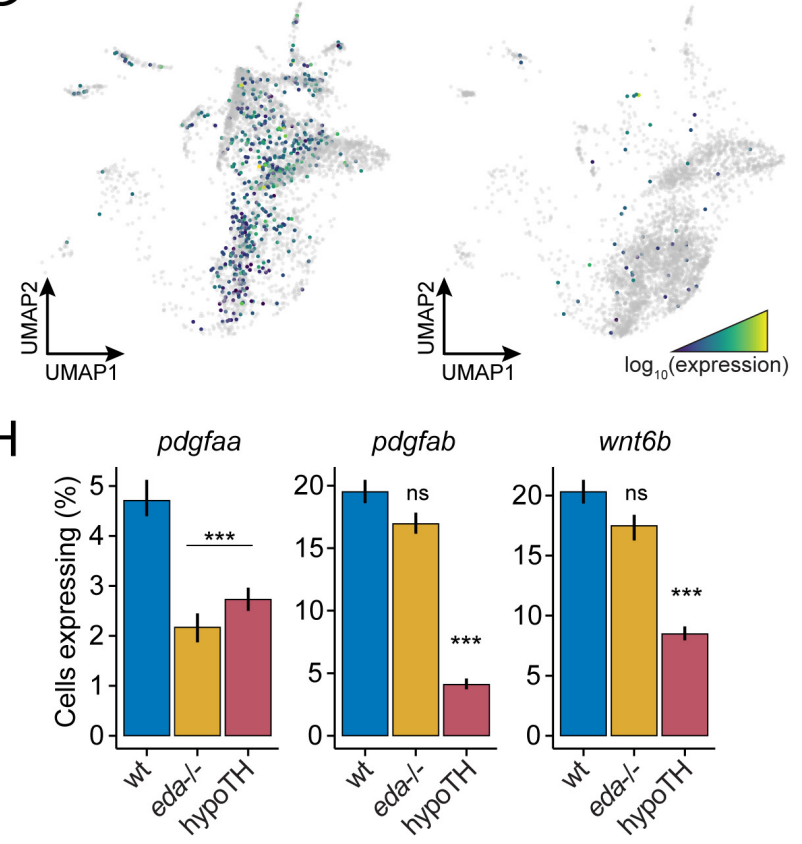

I

\begin{tabular}{r|l} 
pathway & \multicolumn{1}{|c}{ TH-dependent Ligand (q-value < 0.05) } \\
\hline BMP & bmp2b, bmp7a, bmp6, bmp16, rgma \\
Delta-Notch & jag1b \\
FGF & fgf24, fgf13a, fgf18a, fgf12a \\
Hedgehog & shha \\
MAPK & pdgfaa, pdgfab, pdgfba, tgfb3, tgfb2, fgf18a \\
TGF-Beta & tgfb3, tgfb2, fsta \\
Wnt & wnt6b, wnt7ab, wnt3a, wnt7aa, wnt7bb
\end{tabular}


Figure 4. Hypodermis is a pigment cell support cell population. (A) At $9.6 \mathrm{SSL}$, bnc2 mutants have grossly fewer iridophores (pnp4a:palm-mCherry) and melanophores (tyrp1b:palm:mCherry). (B) UMAP visualization of dermal cells and pigment cells, with wild-type in blue and bnc2 mutant in red, shows specific deficiency in hypodermal cells. (C) Heatmap showing $\log _{2}$ proportion of dermal cell subtypes and pigment cells. (D) Orthogonal projections of live, superresolution imaging of dermal cells in wild-type and bnc2 mutants expressing ET37:EGFP. Wild-type hypodermis is a thin, confluent cell layer underneath the more brightly labeled dermal mesenchyme (dm). Stage matched bnc2 mutant dermis had dermal mesenchyme, but lacked a hypodermal layer. (E) Live imaging of fish doubly transgenic for ET37:EGFP to visualize hypodermis, and pnp4a:palm:mcherry to visualize iridophores (irid) or tyrp1b:palm-mCherry to visualize melanophores (mel). Both pigment cell types reside in close contact with hypodermal cells. (F) Dot-plot heatmap showing expression level of known pigment cell trophic factors. (G) Schematic representation of pigment cell microenvironment, stretched in its superficial-deep axis to more clearly render organization of the very flat pigment and hypodermal cells. (H) Potential regulatory linkages between hypodermis and pigment cell types, inferred from expression (black arrows) and published studies. Previously documented interactions among the pigment cells represented by grey arrows. Scale bars: A, $100 \mu \mathrm{m} ; \mathrm{B}, 10 \mu \mathrm{m}$.

Figure 4 appears on the next page 
bioRxiv preprint doi: https://doi.org/10.1101/2021.05.12.443782; this version posted May 13, 2021. The copyright holder for this preprint (which was not certified by peer review) is the author/funder, who has granted bioRxiv a license to display the preprint in perpetuity. It is made available under aCC-BY-NC-ND 4.0 International license.

\section{Figure 4}

A
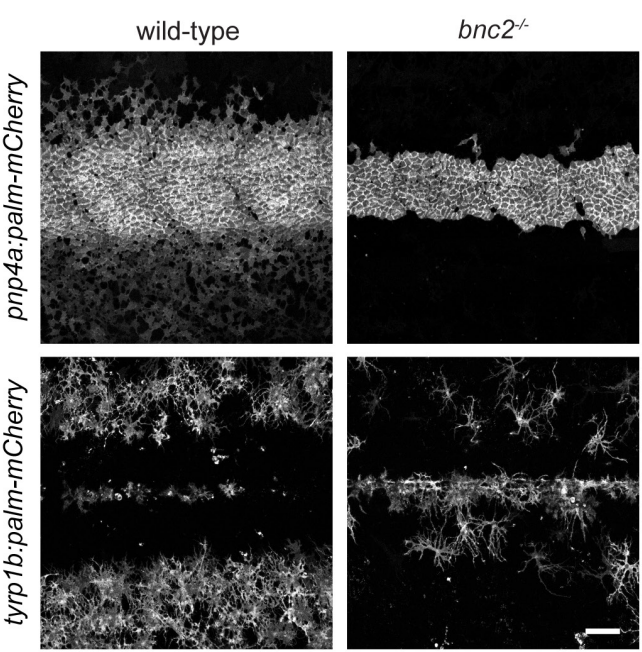

D

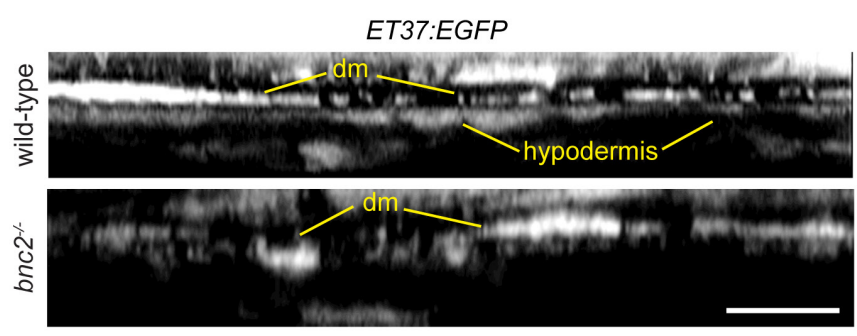

$\mathrm{F}$

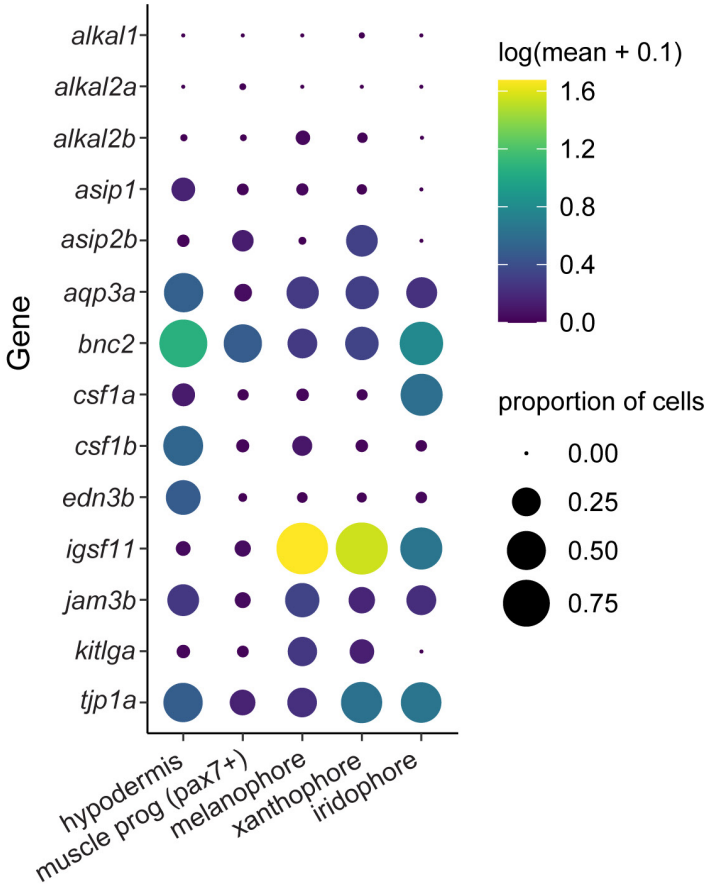

B

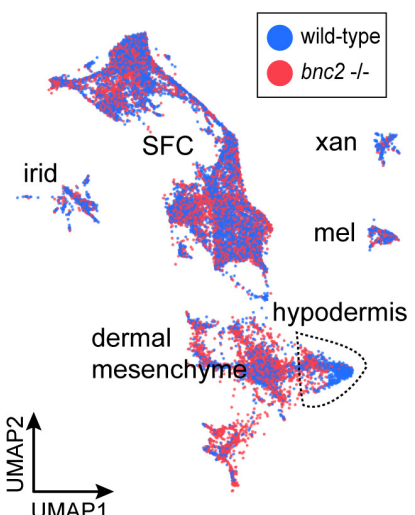

E

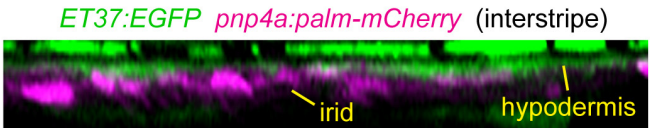

ET37:EGFP pnp4a:palm-mCherry (stripe)

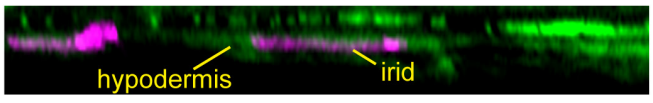

ET37:EGFP tyrp1b:palm-mCherry (stripe)

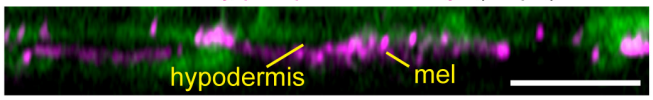

$G$

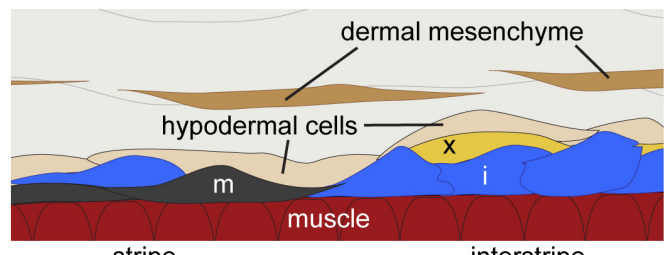

stripe

interstripe

$\mathrm{H}$

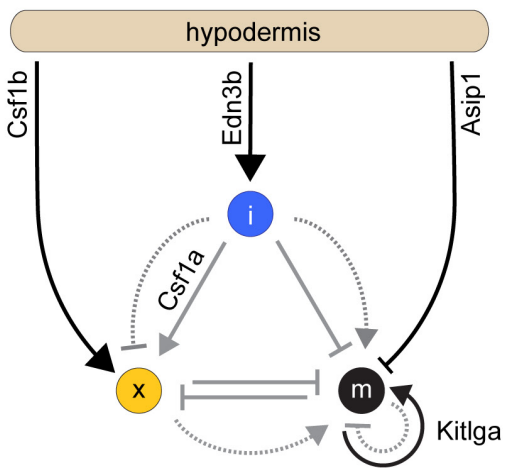


Figure 4 - Supplement 1. Hypodermis regulates iridophore gene expression. (A) Iridophores and melanophores in wild-type and bnc2 mutant skins highlighting the relative dearth of pigment cells in the mutant. (A') Superresolution images of boxed region in (A), iridophores expressing pnp4a:palm-mCherry and orthogonal projection showing both iridophores and dermal cells expressing ET37:EGFP. bnc2 mutant dermis is bounded by dermal mesenchyme (dm) and lacks the thin, confluent hypodermis seen in wt individuals (arrows). (B) UMAP visualizations of pigment cell trophic factors, edn3b and $c s f 1 b$. (C) Loss of hypodermis is associated with a greater number of differentially expressed genes (DEGs) in iridophores than in other pigment cell types. Scale bars: A, $100 \mu \mathrm{m} ; \mathrm{B}, 10 \mu \mathrm{m}$.
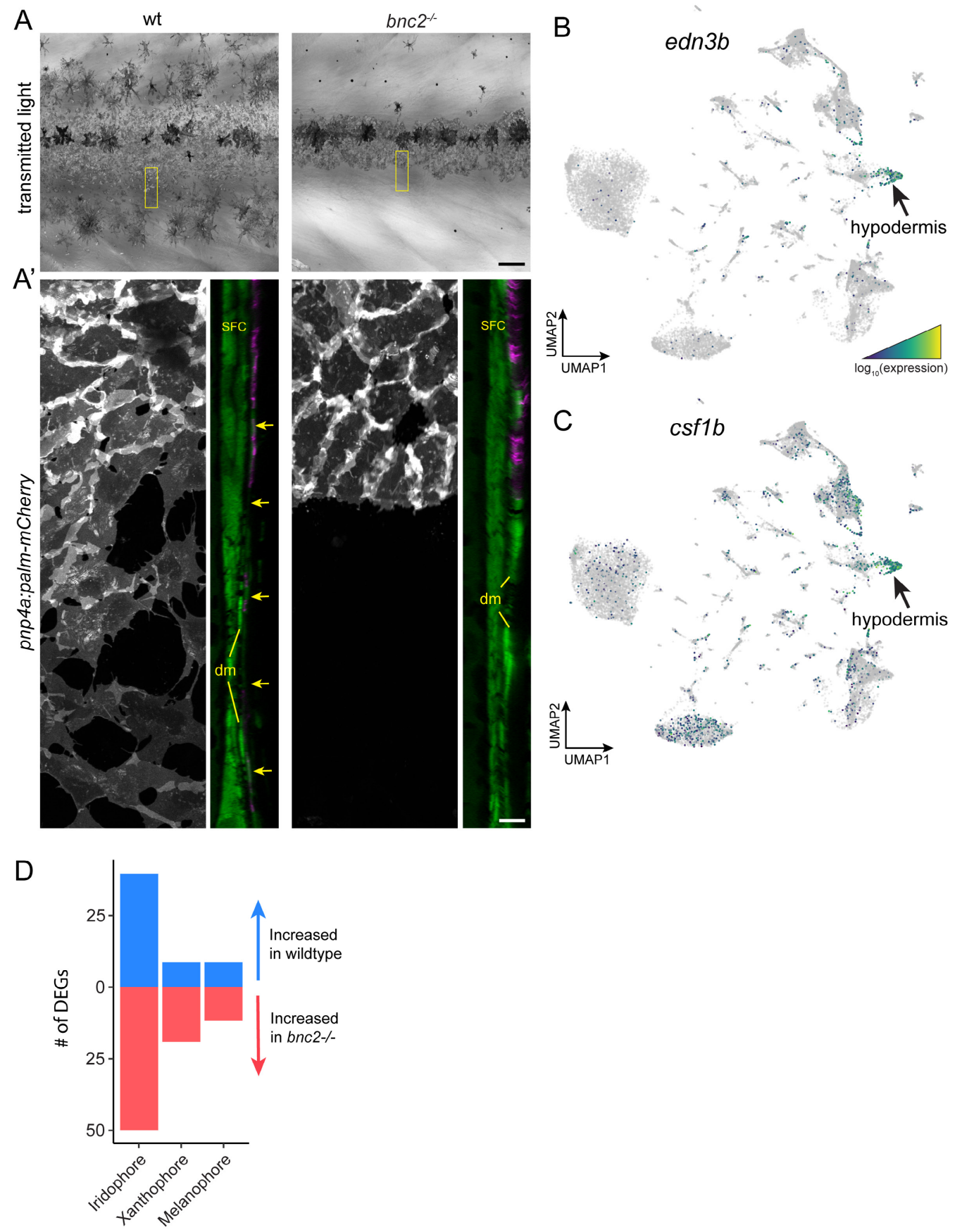